This is a pre-proof version of an article in Sedimentology

Arnaud, E. 2007. Deformation in the Neoproterozoic Smalfjord Formation, northern Norway: an indicator of glacial depositional conditions? Sedimentology, 55: 335-356.

The definitive version is available at www.blackwell-synergy.com 


\section{IAS SEDIMENTOLOGY \\ Journal of the international Association of Sedimentologists}

Deformation in the Neoproterozoic Smalfjord Formation, Northern Norway: an indicator of glacial depositional conditions?

\begin{tabular}{|r|l|}
\hline Journal: & Sedimentology \\
\hline Manuscript ID: & SED-2007-OM-027.R1 \\
\hline Manuscript Type: & Original Manuscript \\
\hline Date Submitted by the \\
Author: & 04-Jun-2007 \\
\hline Complete List of Authors: & Arnaud, Emmanuelle; University of Guelph, Land Resource Science \\
\hline Keywords: & $\begin{array}{l}\text { Neoproterozoic, Varangerfjord, ductile deformation, glaciofluvial, } \\
\text { glaciotectonic }\end{array}$ \\
\hline
\end{tabular}

\section{(5) ScholaroNE \\ Manuscript Central}




\title{
DEFORMATION IN THE NEOPROTEROZOIC SMALFJORD FORMATION, NORTHERN NORWAY: AN INDICATOR OF GLACIAL DEPOSITIONAL CONDITIONS?
}

\author{
Emmanuelle Arnaud \\ Department of Land Resource Science, University of Guelph \\ Guelph, Ontario, N1G 2W1, CANADA \\ earnaud@uoguelph.ca \\ Tel: (519) 824-4120 xt 58087
}

Fax: (519) 824-5730

\author{
Submitted to Sedimentology \\ February 20, 2007 \\ Revised and resubmitted \\ June 4, 2007
}




\begin{abstract}
Recent studies on Neoproterozoic climate change has prompted renewed interests in Neoproterozoic glacial deposits and renewed debates over the criteria used to identify the nature of glacial influence on sedimentation. Analysis of soft sediment deformation structures have provided important clues to distinguish between competing paleoenvironmental interpretations of Quaternary glacial deposits. A similar approach is presented here in the analysis of Neoproterozoic glacial deposits of the Smalfjord Formation, northern Norway. Detailed sedimentological and structural analysis at several sites in the Varangerfjorden area reveals complex soft sediment deformation at various scales in conglomerate, sandstone and diamictite. Deformation is predominantly ductile and includes anticlinal and synclinal folding, flow noses, flame structures, recumbent folding and shear structures. The deformed sediments are predominantly associated with conglomerate and sandstone, which record glaciofluvial and deltaic depositional conditions. Some deformation can be attributed to rapid deposition and slumping, whereas others appear to record shear stress associated with overriding ice. The scale, style and range of deformation together with the coarse-grained nature of the deformed sediments and facies associations suggests these were unfrozen outwash sediments that were overridden by ice and resedimented in a dynamic ice proximal setting. Whereas recent previous studies of diamictite-bearing strata of the Smalfjord Formation had revealed no clear evidence of glacial influence on deposition, deformation structures documented here suggest that glacial conditions prevailed on the basin margin during deposition of Smalfjord Formation sediments, with sedimentary facies and deformation structures typical of temperate ice proximal settings. Keywords: Neoproterozoic, Varangerfjord, ductile deformation, glaciofluvial environment, glaciotectonic
\end{abstract}




\section{INTRODUCTION}

Recent debates about the nature of Neoproterozoic climate change has prompted renewed interest in glacial deposits of that period. Neoproterozoic successions consist of diamictitebearing strata associated with carbonate deposits, traditionally interpreted as recording glacial conditions and post-glacial transgression respectively. Several climatic scenarios have been proposed for these Neoproterozoic successions ranging from 'normal' glaciations similar to those experienced in the Phanerozoic (e.g. Condon et al., 2001; Allen et al., 2004) to the extreme and unprecedented 'snowball Earth' glaciations with global ice covering equatorial oceans (Hoffman et al., 1998; Hoffman and Schrag, 2002).

Part of the discussion on the nature of Neoproterozoic climate change has been, and continues to be, over the controversial origin of diamictite-bearing strata and the criteria used to determine the extent and nature of glacial influence on their deposition (Harland, 1964; Crowell, 1964; Schermerhorn, 1974; Flint, 1975; Hambrey and Harland, 1978; Boulton and Deynoux, 1981; Eyles, 1993; Christie-Blick et al., 1999; Eyles and Januszczak, 2004). Whereas clast characteristics such as striations, faceting and extra-basinal composition have been used to suggest a glacigenic source, the actual conditions at the time of deposition often remain controversial. In addition, like other ancient glacigenic successions, Neoproterozoic successions often consist of reworked glaciomarine sediment gravity flow deposits, where the extent of ice and paleoclimatic conditions are often difficult to establish.

Analysis of synsedimentary deformation structures has been shown to provide important information about the depositional origin of various deposits (Maltman, 1994; Obermeier, 1996; McCarroll and Rijsdijk, 2003). This may be particularly useful to distinguish between deposits 
that form under ice-contact, glacially-influenced or non-glacial conditions as glacitectonic deformation has been shown to leave distinctive characteristics in Quaternary glacial deposits (Croot, 1988; Aber et al., 1989; Benn and Evans, 1996; McCarroll and Rijsdijk, 2003; Hart and Roberts, 1994). Whereas sedimentological and structural analysis of soft sediment deformation in Quaternary-age deposits has received considerable attention (e.g. Hart, 1994; Hambrey and Huddart, 1995; Boulton et al., 1999; Rijsdijk, 2001; Phillips et al., 2002; Winsemann et al., 2003), this remains relatively unexplored in the analysis of ancient glacigenic successions (e.g. Pazos et al., 2003; Kellerhals and Matter, 2003; Allen et al., 2004; Rieu et al., 2006; notable exceptions include Visser et al., 1984 and Le Heron et al., 2005). Neoproterozoic glacial deposits are often preserved in relatively deep-water settings of glaciomarine basins (Eyles, 1993) where deformation may be limited. However, some Neoproterozoic successions record basin marginal conditions, where deformation may provide useful information about paleoenvironmental conditions, ice dynamics and the nature of glacial influence on deposition. In addition, analysis of deformation structures may help to distinguish between competing interpretations of some Neoproterozoic glacial deposits.

This paper provides an example of such an analysis based on the sedimentological and structural analysis of the Neoproterozoic Smalfjord Formation at several sites in the Varangerfjorden area (Fig.1). The purpose of this paper is to characterize the deformation structures found at these sites and to assess their significance in the context of recent debates over the nature of glacial influence on sedimentation.

\section{PREVIOUS STUDIES}




\section{Geological background}

The Smalfjord Formation is one of two diamictite-bearing units at the base of the Vestertana Group (Fig. 2), which unconformably overlies the marine, fluvial and deltaic deposits of the Tanafjord and Vads $\rho$ groups (Bjprlykke, 1967; Banks et al., 1971). The Smalfjord Formation unconformably overlies the stromatolite-bearing Grasdalen Formation, and is in turn overlain by the Nyborg Formation, which consists of predominantly deep marine clastic sediments (Reading and Walker, 1966; Edwards, 1984). Thin and spatially limited exposures of carbonates occur at the base of the Nyborg Formation (Edwards, 1984; Siedlecka and Roberts, 1992). However, the Nyborg Formation does not have a well developed 'cap carbonate' like many other Neoproterozoic successions (Siedlecka et al., 2004).

The Smalfjord Formation is well exposed in the Tanafjorden and Varangerfjorden area of Finnmark, northern Norway, southwest of the Trollfjorden-Komagelva Fault Zone (TKFZ). It is thought to record sedimentation in a pericratonic setting on the edge of an extensional basin (Siedlecka, 1975; Gayer and Rice, 1989; Siedlecka and Roberts, 1995) located at high paleolatitude ( 75E; Torsvik et al., 1995; Torsvik et al., 1996; Torsvik and Cocks, 2005 in Bingen et al., 2005). Sedimentation in Smalfjord times was influenced by regional extensional tectonics along the TKFZ and nearby faults, associated with the development of the Iapetus ocean to the NW and the adjacent Timanian aulacogen to the NE (Siedlecka, 1975; Gayer and Rice, 1989; Siedlecka and Roberts, 1995; Rpe, 2003), though recent studies suggest that the predominant influence was from Timanian extension (Siedlecka et al., 2004). The study area was subsequently affected by compressional tectonics from the NE associated with the Timanian (Baikalian) orogeny in the Late Neoproterozoic (Upper Vestertana Group) and from the W 
associated with the Caledonian orogeny in the Late Silurian-Early Devonian (Siedlecka and Roberts, 1995; Roberts and Siedlecka, 2002).

Radiometrically, the succession is poorly constrained with $\mathrm{Rb}-\mathrm{Sr}$ whole rock isochron

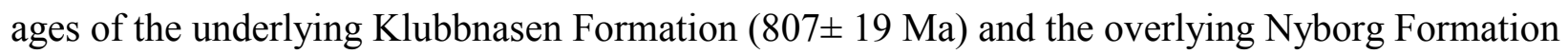
(654 \pm 23 Ma; Sturt et al., 1975; recalculated by Siedlecka and Roberts, 1992). More recently, $\mathrm{Rb}-\mathrm{Sr}$ dating of diagenetic illite from shales of the Stangenes, Nyborg and Stappogiedde formations suggested an age between 630 and $560 \mathrm{Ma}$, consistent with earlier data (Gorokhov et al., 2001). U-Pb and Lu-Hf analysis of detrital zircons from the Rendalen Formation below the Moelv Tillite of southern Norway has yielded an age of $620 \pm 14 \mathrm{Ma}$ (Bingen et al., 2005). If stratigraphic correlation between the Mortensnes Formation in northern Norway and the Moelv Tillite in southern Norway are correct (see discussion below), then this recent detrital zircon date provides a minimum age for the Smalfjord Formation.

Based on lithostratigraphic and biostratigraphic correlations (Hambrey, 1983, Farmer et al., 1992; Vidal and Moczydłowska, 1995), the Smalfjord Formation has otherwise long been considered the older of two glacial intervals in the North Atlantic, which were thought to record a Varangian/Marinoan glaciation (c. $635 \mathrm{Ma}$, Condon et al., 2005). Limited geochemical data on a thin carbonate overlying the Smalfjord Formation is consistent with a Marinoan affinity (Rice, 2004; Halverson et al., 2005; but see Arnaud and Eyles, 2004). Recent discussions have focused on the correlation of the younger glacigenic unit (the Mortensnes Formation) with the Moelv Tillite in southern Norway and the Gaskiers Formation of Newfoundland (Knoll, 2000; Halverson et al., 2005), suggesting a Gaskiers affinity (c. $580 \mathrm{Ma}$; Bowring et al., 2003) for the overlying Mortensnes Formation. Overall, however, these correlations require further study, 
considering the poor radiometric control on this succession and the ongoing debates over global chronostratigraphic correlations (e.g. Kaufman et al., 1997; Kennedy et al., 1998; Knoll, 2000; Evans, 2000; Eyles and Januszczak, 2004; Kendall et al., 2006).

\section{The glacigenic origin of the Smalfjord Formation}

The Smalfjord Formation has traditionally been interpreted as recording glacial conditions based on the classic striated pavement exposed at Bigganjargga (Oaibaččannjar'ga) first described by Reusch in 1891, as well as diamictite-bearing strata and mudstones with dropstones at various sites throughout Finnmark (Fpyn, 1937; Spjeldnaes, 1964; Reading and Walker, 1966; Bjprlykke, 1967; Banks et al., 1971; Edwards, 1975, 1984; Fpyn and Siedlecki, 1980; Laajoki, 2001, 2002). However, other researchers have suggested that many of the deposits may instead record sediment instability and deposition under sediment gravity flow processes in a subaqueous setting (Crowell, 1964; Schermerhorn, 1974; Eyles, 1993; Jensen and Pederson, 1996).

Recent sedimentological analyses of the Smalfjord Formation exposed at Tarmfjorden, and at two other sites along Varangerfjorden (Bigganjargga and Kvalnes) suggested that the diamictites and associated conglomerate, sandstone and mudstone accumulated in a marine setting with limited glacial influence on sedimentation (Arnaud and Eyles, 2002). Coarsegrained facies in the Varangerfjorden area record accumulation by sediment gravity flows on a debris apron, whereas diamictite and mudstone in the Tarmfjorden area record reworking of sediments in a unstable subaqueous setting. The coarse-grained debris at these sites may have been glaciogenic in origin, but a direct glacial influence on the final mode of deposition could not 
be demonstrated (Arnaud and Eyles, 2002, 2004). This is an important distinction considering the extent of ice cover and severity of glaciations recently proposed in Neoproterozoic climate change scenarios. The current study focuses on other sites along Varangerfjorden, where associated conglomerates and sandstones, briefly described by Edwards (1984), are thought to have accumulated at the basin margin.

\section{SEDIMENTARY FACIES}

The Smalfjord Formation exposed along the north shore of Varangerfjorden and on the island of Skjaholmen consist predominantly of conglomerate and sandstone, with a localized outcrop of diamictite. In this paper and in accordance with recent usage, the term diamictite is used to describe poorly-sorted conglomeratic deposits that contain a wide range of particle sizes irrespective of depositional origin (Flint et al., 1960; Eyles, 1993; Hambrey and Glasser, 2003).

\section{Conglomerate}

Conglomerate of the Smalfjord Formation is predominantly matrix-supported, moderately to very poorly sorted, with clasts floating in a medium to coarse-grained sandstone matrix (Fig. $3 \mathrm{~A}-\mathrm{C}$ ). Clast are on average up to $50 \mathrm{~cm}$ in diameter (maximum size of $1.6 \mathrm{~m}$ ), predominantly subangular to subrounded, and of mixed lithology including dolomite, quartzite and sandstone. Local breccias occur. No preferred apparent orientation or imbrication has been observed, with the exception of several units where clasts a-axis are parallel to the bedding surface.

Conglomerate are massive or stratified. Stratification is defined by differences in matrix texture, clast size, abundance, or sorting and is generally horizontal to low angle or deformed. In 
addition, some conglomerates exhibit grading (normal, inverse, coarse-tail normal, coarse-tail inverse), pervasive deformation or cross-bedding (trough-cross or planar) (Fig. 3A-C). Basal contacts are sharp and often erosional.

Individual beds are up to several metres in thickness and are generally laterally traceable over 10s of metres of exposure. Conglomerate beds are either planar tabular or inclined gently over 10 to 100 s of metres of exposure. Conglomerate is most often associated with sandstone or pebbly sandstone.

\section{Sandstone}

Sandstone is muddy fine to coarse grained, moderate to well sorted and most commonly laminated, thinly bedded, or massive (Fig. 3D-E). In several instances, sandstone exhibits normal grading, cross-bedding, or deformation. Some units also contain dispersed clasts (pebbly sandstone) or laterally discontinuous lenses or stringers of conglomerate. Most beds are laterally traceable over 10 s of metres of exposure with sharp basal contacts. At one site, massive medium-grained sandstone exhibits loading into finely-laminated muddy sandstone (Fig. 3D). Sandstone beds are most commonly planar tabular or inclined gently over 10-100s of metres of exposure; some are laterally discontinuous as a result of erosion by an overlying unit. Sandstone is most often associated with conglomerate.

\section{Diamictite}

There is only one diamictite unit in all of the sites studied. It is matrix-supported, stratified and poorly sorted with clasts up to $55 \mathrm{~cm}$ in a muddy sandstone matrix (Fig. 3F). 
Clasts are commonly $<2 \mathrm{~cm}$ in diameter, angular to subrounded, and of mixed lithology.

Striations or faceting of clasts were not observed. The diamictite shows chaotic convoluted and contorted bedding defined by variable texture and deformed rafts of finely laminated muddy sandstone. It occurs as a lens measuring approximately $20 \mathrm{~m}$ in length and up to $1.5 \mathrm{~m}$ in thickness; it is associated with sandstone, conglomerate and breccia.

\section{LATERAL AND VERTICAL DISTRIBUTION OF FACIES}

The distribution of conglomerate, sandstone and diamictite facies was documented using stratigraphic logs, photographs and panel diagrams at Skjaholmen, Handelsneset and Nesseby (Fig. 1). Together with facies characteristics, these data provide important information about the nature of depositional conditions prior to deformation of the sediments.

\section{Skjaholmen Island-Eastern Shore}

Description

The Smalfjord Formation (5 -15 m thick) outcrops over a distance of approximately 50 $100 \mathrm{~m}$ along a SSW-NNE transect. The basal unconformity of the Smalfjord Formation at this location is sharp, planar and erosional. At the base of the section, massive and horizontallybedded sandstone units are interbedded with finely-laminated muddy sandstone and occasional thin beds of conglomerate and breccia (Fig. 4A). Sandstone exhibits contorted and convoluted bedding as well as loaded basal contacts or pillows (Fig. 3D). These sandstone units are erosively overlain by a lens of deformed diamictite approximately $20 \mathrm{~m}$ in length and up to $1.5 \mathrm{~m}$ in thickness (Fig. 3F, 4). The upper contact of this diamictite lens with the overlying 
conglomerate and breccia is sharp and irregular, with these overlying beds onlapping the diamictite. Conglomerate is the dominant sediment type in the uppermost part of the outcrop and laterally associated with the diamictite lens (Fig. 4). Conglomerate is predominantly matrixsupported, and stratified, with occasional cross-bedding, clast-supported texture or clasts a-axis that are parallel to the bedding surface. One paleocurrent measurement from a trough-cross bedded sandstone unit yielded an orientation of 298E. Minor sandstone units in the uppermost section are either laminated to thinly bedded (horizontal or low-angle) or massive with some containing dispersed pebbles less than $2 \mathrm{~cm}$ in diameter. Most beds are laterally traceable over 10s of metres, although conglomerate units at the NNE end of the outcrop typically laterally pinch out or are eroded by an overlying conglomerate (Fig. 4A).

\section{Depositional conditions}

The sandstone, and thin conglomerate and breccia at the base of the succession are interpreted as the product of subaqueous sediment gravity flows (Edwards, 1984; hyperconcentrated and concentrated density flows based on terminology by Mulder and Alexander, 2001). Rapid sedimentation by these flows is indicated by the lack of internal structure in sandstone and conglomerate and the load casts and pillow structures in the interbedded medium and finely laminated muddy sandstone. The angularity and lithology of clasts in the breccia unit suggest limited reworking and transport of the underlying bedrock. The thick sections of stratified and cross-bedded conglomerate that dominate the upper and NNE part of the exposure, are interpreted to record high energy depositional conditions in a braided fluvial system (Edwards, 1984). Predominantly angular to subrounded sandstone in the diamictite 
suggests reworking of local bedrock, with minor dolomitic and granitic clasts coming from farther afield. The depositional origin of the diamictite will be discussed below once the deformation structures within it are described and analysed.

\section{Skjaholmen Island-South-central Shore}

\section{Description}

The Smalfjord Formation (10-15+ m thick) outcrops over a distance of approximately $110 \mathrm{~m}$ along the south-central shore of Skjaholmen Island. The basal unconformity of the Smalfjord Formation is exposed over a distance of approximately $50 \mathrm{~m}$ (Fig. 5A). In contrast to other sites on the island or on the north shore of Varangerfjorden, the unconformity is sharp and highly irregular with brecciated fragments of the underlying formation commonly incorporated into the basal unit of the overlying Smalfjord Formation (Fig.5). The sediments directly overlying the unconformity are variable, changing laterally from a graded matrix-supported conglomerate with deformed bedding to crudely-bedded deformed sandstone with laterally discontinuous lenses of conglomerate (Fig. 5B).

Sandstone is relatively common in these outcrops and is predominantly massive or graded with individual beds ranging between $10-50 \mathrm{~cm}$ in thickness (Fig. 5). A large granite boulder (90 $\mathrm{cm}$ in diameter) was found in massive and graded sandstone. Some sandstone units are horizontally laminated or thinly bedded ( $\mathrm{mm}$ to $10 \mathrm{~cm}$ scale), whereas others exhibit contorted and convoluted bedding defined by discontinuous stringers of conglomerate or changes in sandstone texture. Beds are generally planar and continuous over 10s of metres of exposure; one channelized erosional unit was observed within massive and graded sandstone. The m-scale 
channel was filled with coarse to very coarse sandstone at its base and otherwise with muddy fine to medium-grained finely-laminated sandstone (Fig. 3E).

Conglomerate units at this site are predominantly matrix-supported and stratified and occur in units up to $5 \mathrm{~m}$ in thickness (Fig. 5). One conglomerate unit exhibits crude normal grading, whereas several others contain laterally discontinuous sandstone lenses. Conglomerates in the upper part of the unit are more organized and well bedded (planar) and are laterally equivalent to sandstone exhibiting sinuous to straight-crested asymmetrical ripples on bedding planes. Three paleocurrent measurements from these rippled sandstone units yielded orientations of $287 \mathrm{E}, 248 \mathrm{E}$ and $280 \mathrm{E}$.

\section{Depositional Conditions}

The presence of massive and graded sandstone together with poorly-sorted stratified conglomerate with some grading suggest rapid deposition by hyperconcentrated and concentrated density flows in a subaqueous setting (Mulder and Alexander, 2001). Granite clasts together with brecciated sandstone and mudstone with lithologies similar to the underlying formation suggests reworking from both regional and local sources. The well-bedded conglomerate associated with rippled sandstone in the upper part of this succession records accumulation under high-energy, unidirectional currents.

\section{North Shore Varangerfjorden}

Handelsneset

There are four sites at Handelsneset where conglomerate and sandstone of the Smalfjord 
Formation overlie cross-bedded sandstone of the Fugleberget Formation of the Vads $\rho$ Group (Fig. 6). The four sites appear to represent progressively stratigraphically lower sediments from Site 1 to 4 (Edwards, 1984), although the lack of exposure between sites makes it difficult to establish the lateral continuity and stratigraphic relationships of units beyond the outcrop in which they are found. The unconformity at these sites is highly irregular with several steeply dipping scarps (up to 35 degrees; see data in Fig. 6), although where exposed the erosional surface is smooth. Despite several excellent bedding plane exposures, no striations were observed along the unconformity. Whereas Edwards (1984) described some of these units as diamictite, all poorly sorted coarse-grained units observed at this site have a sandstone or dolomitic sandstone matrix; they are therefore referred to as conglomerate for the purpose of this paper.

At Site \#1, clinoforms of interbedded conglomerate and sandstone outcrop over a distance of approximately $150 \mathrm{~m}$ along a WSW-ENE transect (Fig. 7). Conglomerates are predominantly stratified to massive with some occasional units being clast-supported and others occasionally cross-bedded. Several units exhibit grading (normal and inverse, coarse-tail normal and coarse-tail inverse). Some clasts have their a-axis preferentially parallel to the bedding plane. Sandstone is predominantly deformed, massive, horizontally-laminated with occasional units exhibiting cross-bedding and normal grading. Conglomerate units exhibit a backstepping pattern towards the ENE in the lower section of the outcrop followed by progradation towards the WSW in its upper part (Fig. 7B).

At Site \#2, conglomerates of the Smalfjord Formation occur in discontinuous outcrops over an area of $100 \times 30 \mathrm{~m}$. The conglomerate is very similar to that found at site \#1, with one 
notable exception where clasts are very well sorted and rounded. Whereas units can be identified based on differences in matrix texture, clast size and abundance or sorting, exposures do not allow stratigraphic and lateral facies relationships to be well defined.

At Site \#3, Smalfjord Formation sediments 3-8 m thick are well exposed over a distance of approximately $50 \mathrm{~m}$ along an E-W transect. The lowest three metres of the outcrop are characterized by complex deformation structures in discontinuous beds of poorly-sorted conglomerates (described in detail below). In contrast, the sediments in the upper five metres are relatively laterally continuous and consist of 30-100 cm thick beds of moderately-sorted and stratified conglomerates and horizontally-bedded or massive sandstone.

At Site \#4, Smalfjord Formation conglomerate and sandstone up to several metres in thickness outcrop over a distance of $200 \mathrm{~m}$ along a WSW-ENE transect (Fig. 8). Conglomerate are stratified and matrix-supported whereas sandstone are deformed, massive, laminated (either horizontally or at low angle), and in some cases cross-stratified. Conglomerate beds continue to the WSW for another $50 \mathrm{~m}$, where they exhibit $\mathrm{m}$-scale convoluted and contorted bedding. Overall these conglomerate and sandstone show an offlapping geometry towards the WSW.

Nesseby

Nesseby is located along the northern shore of Varangerfjorden, less than $10 \mathrm{~km}$ to the West of Handelsneset (Fig. 1). At this site, the Smalfjord Formation is composed of up to $10 \mathrm{~m}$ of planar to gently inclined interbedded sandstones and conglomerates, exposed along an E-W trending outcrop over approximately $250 \mathrm{~m}$ (Fig. 9). There is no diamictite or exposures of the underlying Fugleberget or Veinesbotn formations at this site. Sandstone are massive or 
horizontally-laminated and bedded. Massive sandstone units, 30 to $100 \mathrm{~cm}$ thick, exhibit pinchand-swell geometry over 10s of metres. Conglomerate units are well stratified with individual beds up to $20 \mathrm{~cm}$ thick exhibiting subhorizontal to inclined bedding. Sandstone and conglomerate units are laterally continuous over 10s of metres, either pinching out laterally or being eroded out by overlying units. Conglomerate units show an apparent progradation towards the West.

\section{Depositional conditions}

The poorly-sorted nature and the presence of grading in some conglomerate units suggests accumulation as hyperconcentrated density flows as originally proposed by Edwards (1984). Sandstone are interpreted as accumulating under upper plane bed flow regime (horizontally laminated facies) or as a result of concentrated flows (low-angle or massive facies) along an inclined depositional surface. In some cases, internal structure may not be visible in outcrop or may have been lost by dewatering and liquefaction (massive facies). At both sites, the geometry of individual conglomerate and sandstone beds and their overall clinoform geometry suggests accumulation on the low-angle (up to 11E) depositional surface of a fan or delta (Edwards, 1984). Backstepping and progradational patterns in the distribution of conglomerate beds suggests proximity to the coarse grained sediment source fluctuated over time. The increased abundance of sandstone from site 1 to site 4 at Handelsneset may reflect a decrease in grain size associated with distance from source. However, the exact stratigraphic relationship of units between all sites on the North shore of Varangerfjorden remains unclear, such that this cannot be confirmed. 


\section{DEFORMATION STRUCTURES}

\section{Description}

Some sediment exposed at Handelsneset and Skjaholmen exhibit significant softsediment deformation. Deformation, which occurs at various scales ( $\mathrm{cm}$ to $\mathrm{m}$ ), is predominantly ductile, and can be characterised as simple shear, compressional and vertical in style (Fig. 10; terminology after McCarroll and Rijsdijk, 2003). Deformation includes contorted and convoluted bedding with symmetric and asymmetric, anticlinal and synclinal folds (Fig. 10C-F, H, I-L) These folds range from open and gentle to tight and isoclinal; their axial plane dips range from upright, through inclined to recumbent. Simple shear structures (such as sheared folds, tectonic lamination or sedimentary units that show lateral attenuation; Fig. 10G), flow noses (Fig. 10A-B), load casts, and flame-like structures are also found in these sediments. These deformation structures are often defined by differences in texture or colour changes related to differences in matrix lithology. Basal contacts of deformed conglomerate units often show incorporation of underlying sediments. Brittle deformation is rare; several examples of smallscale normal and reverse faulting were observed, with offsets ranging from $<1$ to $7 \mathrm{~cm}$.

At Skjaholmen, the deformation predominantly consists of convoluted and contorted bedding, loading and flame structures as well as recumbent folding. The diamictite at E. Skjaholmen is characterized by convoluted and contorted bedding (Fig. 3F). Variable texture and deformed rafts of finely laminated muddy sandstone impart a chaotic structure to this deposit. Loading is also particularly evident at the base of the underlying sandstone, which are interbedded with muddy sandstone at the base of the eastern shoreline outcrop (Fig. 3D). 
Recumbent folding is documented in sandstone and conglomerate at the south-central outcrop. The recumbent folding is located downslope of an inclined massive sandstone unit (Fig. 10C-D).

In contrast, deformation at Handelsneset (site 3) is relatively more complex and pervasive throughout the basal conglomerate and sandstone of the Smalfjord Formation (Fig. 10A-B, I-L, 11). Contorted and convoluted bedding, simple shear structures, flow noses and flame-like structures associated with shear and contorted and convoluted bedding are visible in a series of 'walls' or panels that cut in and out at various angles to the overall WNW-ESE trend of the outcrop at Site \#3 (Fig. 11). The complexity of deformation is laterally and vertically highly variable going from complex and severe to completely undeformed within distances of 1-15 m. Deformed conglomerate are closely associated and interbedded with undeformed conglomerate and sandstone (massive, horizontally and cross-bedded or graded; Fig. 10 I, 11 see panel 6 and panel 2).

Close examination of this outcrop reveals discontinuous zones of deformation at two different stratigraphic levels (Fig. 11). The deformation zones are up to a several metres in thickness and can extend up to $25 \mathrm{~m}$ laterally along the outcrop. The first deformed zone occurs immediately over the basal unconformity in all panels, except panels 8 and 13 (Fig. 11, Unit A). It consists of convoluted and contorted bedding, simple shear structures (tectonic laminations, attenuated beds and sheared folds), and a ridge-like feature several metres wide and approximately $1 \mathrm{~m}$ in height with associated folding and flow noses on either side of the ridge (Fig. 10 I-L; 11). At the eastern end of the outcrop (Panels 2-3 and 3), Unit A exhibits an upward decrease in the intensity and abundance of deformation structures from a highly deformed basal unit with abundant shear structures, to only broadly deformed stratification and no structures in 
the upper most part of the outcrop. This upward decrease in deformation structures continues in adjacent outcrops over several 10's of metres to the NE of Panel 3.

This first deformation zone is overlain by a relatively undeformed conglomerate unit (Unit B), which occurs in panels 5 to 8 and 13 (Fig. 11). Unit B is characterized by common large clasts and terminates in a flow nose in Panel 5 (Fig, 10L, 11). Unit B is overlain conformably by the second deformation zone (Fig. 11, Unit C), which contains convoluted and contorted bedding, sheared folds, tectonic lamination or sedimentary units that show lateral attenuation and flame structures, as well as a small flow nose (Fig. 10B). Unit C occurs from Panel 13 in the West to panel 4-2 in the East. Unit C is in turn overlain by undeformed stratified conglomerate of Unit D, which contains localized and crude cross bedding (Fig. 11; panel 7) and grading (Fig. 11, panel 8). The lower contact of Unit D is erosive to conformable.

Although there is significant variability, deformation structures exhibit an apparent orientation towards the West in outcrops at Handelsneset (Fig. 11). Most exposures provide only an apparent dip of bedding, thereby limiting the potential for paleostress analysis. However, the true attitude of beds oriented towards the upper left corner of panel 8 in Unit C (an apparent attitude towards the West) were resolved to be 307E/16E (strike/dip). Simple shear structures along this bedding suggests a principal stress applied from the NE (37E). Similar paleostress is inferred in panels 3 and 6 based on the similar orientation of bedding, deformation structures and outcrop exposure.

\section{Interpretation}

Deformation structures can be analysed according to deformation mechanisms, driving 
forces and triggers (Owen, 1987). Deformation mechanisms such as liquefaction and fluidization are processes that enable sediments to deform, whereas driving forces are the stresses acting on the sediments including graviational forces, unevenly distributed confining loads, unstable density gradients and tangential and vertical shear stresses. Triggers are the conditions that provide the driving forces or stresses, such as rapid sedimentation, earthquakes, glacier ice, breaking waves, and flow surges. Other aspects to consider are the deformation styles (pure shear, simple shear, compressional, vertical and undeformed), the relative scale of each deformation style, the magnitude and direction of stress as well as the stratigraphic position and relative timing of the deformation (McCarroll and Rijsdijk, 2003). While many deformation styles are common to several trigger mechanisms, several specific deformation structures as well as their complexity and scale can be used to identify the original mechanism of deformation. The depositional origin and significance of the deformation observed in the Smalfjord Formation sediments is discussed in the context of this framework.

The presence of closely associated deformed and undeformed sediments as well as the erosional upper contact of some deformed units suggests that deformation occurred as these sediments were deposited or shortly after (Maltman, 1994), rather than as a result of postdepositional Caledonian or Timanian tectonics. The predominantly ductile deformation observed at small $(\mathrm{cm})$ to large $(\mathrm{m})$ scales at all sites suggests loss of sediment yield strength through increased porewater pressure and liquefaction of unfrozen sediments (deformation mechanism; sensu Owen, 1987).

Load casts and associated flame structures developed in interbedded medium and muddy sandstone at East Skjaholmen are interpreted as resulting from rapid deposition of sand onto 
muddy sand and unstable density gradients (driving force; sensu Owen, 1987). The recumbent folding associated with an inclined depositional surface on SW Skjaholmen is likely the result of gravitational forces associated with that paleoslope (driving force; sensu Owen, 1987). The deformation style observed within the diamictite at Skjaholmen is most consistent with unstable and reworked poorly sorted materials. The diamictite did not exhibit any shear planes, tectonic laminations, or an upward decrease in visible deformation structures typical of subglacial constructional deformation (Benn and Evans, 1996). The deformation on Skjaholmen is therefore attributed to slumping and rapid deposition of sediments with slightly different density characteristics (trigger mechanism; sensu Owen, 1987).

At Handelsneset, deformation structures resulted from a relatively more complex combination of compressional and simple shear stresses during or shortly after deposition (driving forces, sensu Owen, 1987. Convoluted and contorted bedding with anticlinal and synclinal folding are indicative of compressional stresses. Shear structures such as the sheared folds, tectonic lamination and attenuated beds recorded in these outcrops are indicative of low shear strain and simple shear stresses (Hart and Roberts, 1994).

In terms of triggers, simple shear stresses can be produced by water currents, sediment gravity flows and/or glacier ice, whereas compressional stresses can result from sediment gravity flows and/or glacial ice (Owen, 1987; Maltman, 1994; Nardin, 1969; Hart and Boulton, 1991). Sedimentary structures indicative of high current velocities such as cross bedding are rare and poorly developed at Handelsneset. Hummocky cross stratification (HCS) typical of storm conditions are also absent, such that water currents as a trigger mechanism is deemed unlikely. The presence of variable slopes ranging from 2 to 35 degrees along the basal 
unconformity of the Smalfjord Formation underlying deformed sediments of Unit A and in nearby outcrops (sites 1 and 4; Fig. 6) suggests that gravity-triggered debris flows may account for some of the observed deformation. The presence of several flow noses (e.g. Unit B and in Panel 7), which are typical of reworked rather than glacitectonized sediments (Hart and Roberts, 1994), is also consistent with a sediment gravity flow origin as a trigger mechanism.

Several lines of evidence suggest that glacier ice also played a significant role in the observed deformation. The complexity and scale of the observed deformation zones is most consistent with polyphase glacitectonic deformation of glaciofluvial sediments reported elsewhere (Benn and Evans, 1996; Philips et al., 2002; McCarroll and Rijsdijk, 2003). The upward decrease in severity and abundance of deformation structures at the eastern end of the Handelsneset outcrops is typical of an upward increase in strain found in subglacial settings where sediments closest to the overlying load of ice are so deformed that they appear homogenized (Benn and Evans, 1996; McCarroll and Rijsdijk, 2003). In glaciated settings, the presence of low shear stress indicators such as the small scale folds and overturned structures found in most of the panels at Handelsneset, is typical of ice marginal settings (Hart and Roberts, 1994). The ridge-like feature observed in panels 5 and 6 is also typical of small-scale ice push features developed as a result of a winter ice readvance (Boulton et al., 1999) with thrusting along a well defined shear plane on the ice contact slope (right side) and remobilization of sediments and slumping on the ice distal slope (left side; Fig.10I).

An interpretation that combines the effects of deformation by ice and debris flows is preferred over an interpretation by a single mechanism for several reasons. First, deformation styles indicative of both mechanisms are present. The presence of flow noses is most typical of 
debris flows (Hart and Roberts, 1994). The complexity and scale of the deformation as well as the decrease in deformation structures observed at the NE end of the outcrops (incremental strain profile) is most consistent with sediments that have experienced deformation by ice. Second, the high pore water pressure associated with liquefaction of such conglomeratic material is best explained in a proglacial setting. In these settings, high pressures can be achieved by confining water between overlying ice or permafrost and a frozen substrate at depth or in adjacent areas, thereby preventing drainage within typically well-drained conglomerate (e.g. Boulton et al., 1999). Third, the upper deformation zone (Fig. 11; Unit C) overlies the relatively flat upper surface of Unit B, such that it is difficult to assign deformation in this unit to variable topography and remobilization of sediments. Fourth, shear structures are present throughout these deposits rather than being concentrated at their base, as often found in sediment gravity flow deposits (Nardin, 1969; Hart and Roberts, 1994; Mulder and Alexander, 2001). Lastly, settings that are dominated by sediment gravity flow processes typically exhibit deformation resulting from loading and water escape. Although some flame structures were observed, these are predominantly associated with shear structures, tectonic lamination and attenuated lenses of sediments. Flame structures associated with load casts typically found in rapidly-deposited sediment gravity flow deposits are conspicuously absent from the outcrops at Handelsneset. In conclusion, there is evidence consistent with both deformation by ice and debris flow and this, in itself, suggests these deformation structures formed in a proglacial settings where sediments can be overriden by ice and buldozed or pushed in front of an advancing ice margin, but are also often remobilized as debris flows due to melting of supporting ice, abundant meltwater, and variable relief on the underlying substrate. 
The architecture, geometry, lateral extent and internal characteristics of the deformed and undeformed Units (A - D) suggest the following sequence of events. Ice appears to have overridden the conglomerate of basal Unit A at the eastern end of the outcrop, leaving a seasonal ice push feature in Panels 5 and 6. The relatively undeformed and onlapping Unit B was likely deposited subsequently as a hyperconcentrated debris flow, during a temporary ice retreat from the immediate area. Additional conglomerate was deposited as Unit C. Both Unit C and the upper contact of Unit B were subsequently deformed by simple shear and compressional stresses coming from the NE. The complexity, scale and styles of deformation, as well as the incorporation of large boulders and sediment from the relatively coherent Unit B, suggest that ice also overrode these sediments. The overlying contact is erosional such that an incremental strain profile similar to that found at the Eastern end of the outcrop in Unit A may not have been preserved. Unit D appears to record a return to the deposition of crudely bedded conglomerate (Panel 7, Fig. 11) with some evidence of reworking by high energy unidirectional currents.

The paleostress data, which suggests stress was applied from the NE, is limited such that its significance is difficult to establish. It is inconsistent with both the measured paleoslope of the underlying substrate (dipping towards ENE, NE or NW; Fig. 6) or previously published paleo-ice flow directions (SE-NW or E-W based on striations and relict roche moutonnées at Bigganjargga; Bjprlykke, 1967; Jensen and Pedersen, 1996; Rice and Hofmann, 2000; Laajoki, 2001, 2002, 2003; or N-S and NW-SE based on the regional study of Edwards, 1984). The one measurement likely reflects very localized and variable conditions as supported by the apparent random orientation of many other deformation structures in the exposed outcrops, though further study would be required to confirm this conclusion. 
In conclusion, the Smalfjord sediments at Handelsneset were probably deformed in an ice proximal glaciofluvial/deltaic setting. High pore water pressures within conglomerate allowed these sediments to liquefy and deform. Driving forces included compressional and simple shear stresses, with deformation triggers from an overriding or a nearby advancing ice margin and downslope remobilization of sediments in a highly dynamic depositional environment.

Deformation is often expressed where slight differences in the matrix texture and lithology occur. This is consistent with previous findings that suggest lithological heterogeneity in ice proximal sediments is another important control on deformation style (Phillips et al., 2002). Undeformed bedded sediments suggest deposition under unidirectional currents and localized meltwater flow. Further paleostress analysis is required to assess the significance of the NE paleostress direction. The apparently random distribution of several deformation structures at Handelsneset is consistent with a proglacial interpretation as sediment instability and uneven topography often lead to highly variable paleostress directions.

\section{DISCUSSION}

The glacial origin of the Smalfjord Formation has been based on the striated pavement at Bigganjargga, as well as diamictite and some mudstone with dropstones (e.g. Reading and Walker, 1966; Bjprlykke, 1967; Edwards, 1984). The extent of glacial influence on the deposition of diamictite units has been the subject of recent debates (e.g. Jensen and Pedersen, 1996, 1997; Edwards, 1997, 2004; Arnaud and Eyles, 2002, 2004). Earlier models emphasized a subglacial origin for many of the diamictite units, with alternating diamictite and associated sediments recording advances and retreats of ice. More recent studies at Tarmfjorden, 
Bigganjargga and Kvalnes (Arnaud and Eyles, 2002, 2004) however demonstrated that the sedimentary characteristics, facies associations and outcrop geometries are more consistent with a sediment gravity flow origin for the diamictite. At these sites, there was very limited evidence of deposition by ice or glacially-influenced conditions at the time of deposition such that diamictite could not be used as proxies for glacial conditions.

The diamictite unit on the island of Skjaholmen is interpreted as a sediment gravity flow deposit based on the style of deformation within the unit and its close association with subaqueous hyperconcentrated and concentrated density flows (underlying sandstone and immediately overlying conglomerate). The convoluted and contorted bedding within the diamictite and the chaotic nature of this deformation is most consistent with reworking and incomplete mixing in an unstable environment, which may have been subaerial or subaqueous. The diamictite itself does not contain any evidence of direct glacial influence on its deposition. It does not exhibit high shear stress indicators such as shear planes, tectonic laminations, or an upward increase in deformation typical of subglacial constructional deformation and lodgement tills described in recent glacial deposits (Hart and Roberts, 1994; Benn and Evans, 1996, McCarroll and Rijsdisjk, 2003). In the end, the indirect glacial influence on this diamictite can only be inferred from its close lateral association with both subaqueous sediment gravity flows and high-energy braided fluvial conglomerate, a typical facies associations described from ice marginal environments (Boulton, 1972; Lawson, 1982; Philips et al., 2002). In contrast, the scale, complexity and the nature of deformation observed in conglomerate and sandstone at Handelsneset does suggests direct glacial influence on deposition. The findings presented here thus confirms the glacial origin of these Neoproterozoic 
deposits and demonstrates that ice cover was variable throughout the basin. The sections exposed at Kvalnes, Tarmfjorden and Bigganjargga area record sediment reworking and instability under shallow to deep marine conditions with very limited evidence of glacial influence on deposition (Arnaud and Eyles, 2002, 2004). At Skjaholmen and Nesseby, glaciofluvial and ice marginal conditions are inferred primarily on the basis of facies associations. In contrast, the deformation of conglomerate at Handelsneset suggests that these sediments were directly affected by overriding ice.

This study demonstrates that the analysis of soft sediment deformation structures in conjunction with traditional facies analysis can provide useful paleoenvironmental information in Precambrian-age sediments. Detailed analysis of the structures can help identify the paleostress directions, driving mechanism, driving forces and triggers responsible for the deformation. Like any other sedimentary characteristics, high quality outcrop exposures with sufficient lateral and vertical extent are necessary to make inferences about the origin of deformation structures. Considering the age of the deposits, the tectonic history of the deposits must also be carefully evaluated to rule out post-depositional deformation. In this context, analysis of basin margin strata from Neoproterozoic or other ancient glacigenic successions can yield a better understanding of paleoenvironmental conditions and may help to better resolve the relative influence of glacial processes on deposition.

\section{CONCLUSION}

The Smalfjord Formation at Skjaholmen, Handelsneset, and Nesseby consists predominantly of conglomerate and sandstone. These are interpreted as glaciofluvial/deltaic 
deposits, which accumulated on the basin margin. A variety of soft sediment deformation structures are described from these sediments including recumbent folding, convoluted and contorted bedding, flow noses, flame and shear structures. The deformation is predominantly ductile, and occurs in relatively simple to highly complex forms at a variety of scales (cm to m). The deformation at Skjaholmen resulted from a combination of liquefaction and either gravitational forces or unstable density gradients associated with slumping and rapid deposition. In contrast, the deformation at Handelsneset resulted from liquefaction and both compressional and shear stresses associated with ice overriding, and reworking of unstable sediments in an ice marginal setting. Similar analysis of deformation structures in other Neoproterozoic successions where basin margin sediments are preserved, can provide important constraints on the extent of ice and the nature of paleoenvironmental conditions during these controversial glacial periods.

\section{ACKNOWLEDGEMENTS}

Funding for this project was provided through an NSERC Discovery Grant. Comments made on an earlier draft by Peter Martini were greatly appreciated. I would also like to thank Steve Aspden for his assistance in the field, Laura Weaver for her assistance in drafting figures and Kenneth Rijsdijk and an anonymous reviewer for reviewing this manuscript. 


\title{
REFERENCES CITED
}

Aber, J.S., Croot, D.G. and Fenton, M.M. 1989. Glaciotectonic landforms and structures.

Glaciology and Quaternary Geology. Kluwer Academic Publishers, Dordrecht, 200 pp.

\begin{abstract}
Allen, P.A., Leather, J. and Brasier, M.D. 2004. The Neoproterozoic Fiq glaciation and its aftermath, Huqf Supergroup of Oman. Basin Research, 16: 507-534.
\end{abstract}

\begin{abstract}
Arnaud, E. and Eyles, C.H. 2002. Glacial influence on Neoproterozoic sedimentation: the Smalfjord Formation, northern Norway. Sedimentology, 49: 765-788.
\end{abstract}

\begin{abstract}
Arnaud, E. and Eyles, C.H. 2004. Glacial influence on Neoproterozoic sedimentation: the Smalfjord Formation, northern Norway - reply. Sedimentology, 51: 1423-1430.
\end{abstract}
Banks, N.L., Edwards, M.B., Geddes, W.P., Hobday, D.K. and Reading, H.G. 1971. Late Precambrian and Cambro-Ordovician sedimentation in East Finnmark. Norges Geologiske Undersokelse, 269: 197-236.

\begin{abstract}
Benn, D.I. and Evans, D.J.A. 1996. The interpretation and classification of subglaciallydeformed materials. Quaternary Science Reviews, 15: 23-52.
\end{abstract}
Bingen, B., Griffin, W.L., Torsvik, T.H. and Saeed, A. 2005. Timing of Late Neoproterozoic glaciation on Baltica constrained by detrital zircon geochronology in the Hedmark Group, south-


est Norway. Terra Nova, 17: 250-258.

Bjprlykke, K. 1967. The Eocambrian Reusch moraine at Bigganjargga and the geology around Varangerfjord Northern Norway. Norges Geologiske Undersokelse, 251: 18-44.

Boulton, G.S. 1972. Modern arctic glaciers as depositional models for former ice sheets. Journal of the Geological Society, London, 128: 361-393.

Boulton, G.S. and Deynoux, M. 1981. Sedimentation in glacial environments and the identification of tills and tillites in ancient sedimentary sequences. Precambrian Research, 15: $397-422$.

Boulton, G.S., van der Meer, J.J.M., Beets, D.J., Hart, J.K. and Ruegg, G.H.J. 1999. The sedimentary and structural evolution of a recent push moraine complex: Holmstrombreen, Spitsbergen. Quaternary Science Reviews, 18: 339-371.

Bowring, S., Myrow, P., Landing, E., Ramezani, J. and Grotzinger, J. 2003.

Geochronological contraints on terminal Neoproterozoic events and the rise of metazoans. Geophysical Research Abstracts, 5: 13219.

Christie-Blick, N., Sohl, L.E. and Kennedy, M.J. 1999. Considering a Neoproterozoic Snowball Earth. Science, 284: 1087. 
Condon, D., Zhu, M., Bowring, S., Wang, W., Yang, A. and Jin, Y. 2005. U-Pb Ages from the Neoproterozoic Doushantuo Formation, China. Science, 308: 95-98.

Condon, D.J., Prave, A.R. and Benn, D.I. 2001. Neoproterozoic glacial-rainout intervals: observations and implications. Geology, 30: 35-38.

Croot, D.G. (Ed), 1988. Glaciotectonics: Forms and Processes. A.A. Balkema Publishers, Rotterdam, $212 \mathrm{pp}$.

Crowell, J.C. 1964. Climatic significance of sedimentary deposits containing dispersed megaclasts. In: Problems in palaeoclimatology (Ed A.E.M. Nairn), pp. 86-99. Interscience Publishers, London.

Edwards, M.B. 1975. Glacial retreat sedimentation in the Smalfjord Formation, Late Precambrian, North Norway. Sedimentology, 22: 75-94.

Edwards, M.B. 1984. Sedimentology of the Upper Proterozoic glacial record, Vestertana Group, Finnmark, North Norway. Norges Geologiske Undersokelse Bulletin, 394: 76 pp.

Evans, D.A.D. 2000. Stratigraphic, geochronological, and paleomagnetic constraints upon the Neoproterozoic climatic paradox. American Journal of Science, 300: 347-433. 
Eyles, N. 1993. Earth's glacial record and its tectonic setting. Earth Science Reviews, 35: 1-248.

Eyles, N. and Januszczak, N. 2004. 'Zipper-rift': a tectonic model for Neoproterozoic glaciations during the breakup of Rodina after 750 Ma. Earth Science Reviews, 65: 1-73.

Farmer, J., Vidal, G., Moczydlowska, M., Strauss, H. and Ahlberg, P. 1992. Ediacaran fossils from the Innerelv Member (late Proterozoic) of the Tanafjorden area, northeastern Finnmark. Geological Magazine, 129: 181-195.

Flint, R.F. 1975. Features other than diamicts as evidence of ancient glaciations. In: Ice Ages: Ancient and Modern (Eds A.E. Wright and F. Morsley), pp. 121-135. Seelhouse Press, Liverpool.

Flint, R.F., Sanders, J.E. and Rodgers, J. 1960. Diamictite, a substitute term for symmictite. Bulletin of the Geological Society of America, 71: 1809-1810.

Fpyn, S. 1937. The Eo-cambrian series of the Tana District, north Norway. Norsk Geologisk Tidsskrift, 17: 65-164.

Fpyn, S. and Siedlecki, S. 1980. Glacial stadials and interstadials of the Late Precambrian Smalfjord Tillite on Lakesfjordvidda, Finnmark, North Norway. Norges Geologiske Undersokelse, 358: 31-45. 
Gayer, R.A. and Rice, A.H.N. 1989. Palaeogeographic reconstruction of the pre- to syn-Iapetus rifting sediments in the Caledonides of Finnmark, N. Norway. In: The Caledonide Geology of Scandinavia (Ed R.A. Gayer), pp. 127-139. Graham \& Trotman, London.

Gorokhov, I.M., Siedlecka, A., Roberts, D., Melnikov, N.N. and Turchenko, T.L. 2001. RbSr dating of diagenetic illite in Neoproterozoic shales, Varanger Peninsula, northern Norway. Geological Magazine, 138: 541-562.

Halverson, G.P., Hoffman, P.F., Schrag, D.P., Maloof, A.C. and Rice, A.H.N. 2005. Toward a Neoproterozoic composit carbon-isotope record. Geological Society of America Bulletin, 117: $1181-1207$.

Hambrey, M.J. 1983. Correlation of Late Proterozoic tillites in the North Atlantic region and Europe. Geological Magazine, 120: 209-232.

Hambrey, M.J. and Glasser, N.F. 2003. Glacial sediments: processes, environments and facies. In: Encyclopedia of Sediments and Sedimentary Rocks (Ed G.V. Middleton), pp. 316-331. Kluwer Academic Publishers, Dordrecht.

Hambrey, M.J. and Harland, W.B. 1978. Analysis of Pre-Pleistocene glacigenic rocks: aims and problems. In: Moraines and Varves (Ed C. Schluchter), pp. 271-275. A.A. Balkema 
Publishers, Rotterdam.

\author{
Hambrey, M.J. and Huddart, D. 1995. Englacial and proglacial glaciotectonic processes at the \\ snout of a thermally complex glacier in Svalbard. Journal of Quaternary Science, 10: 313-326. \\ Harland, W.B. 1964. Critical evidence for a great infra-cambrian glaciation. Geologisches \\ Rundschau, 54: 45-61.
}

Hart, J.K. 1994. Proglacial glaciotectoni deformation at Melabakkar-Asbakkar, west Iceland. Boreas, 23: 112-121.

Hart, J.K. and Boulton, G.S. 1991. The interrelation of glaciotectonic and glaciodepostional processes with the glacial environment. Quaternary Science Reviews, 10: 335-350.

\begin{abstract}
Hart, J.K. and Roberts, D.H. 1994. Criteria to distinguish between subglacial glaciotectonic and glaciomarine sedimentation, I. Deformation styles and sedimentology. Sedimentary Geology, 91: 191-213.
\end{abstract}

Hoffman, P.F., Kaufman, A.J., Halverson, G.P. and Schrag, D.P. 1998. A Neoproterozoic snowball earth. Science, 281: 1342-1346.

Hoffman, P.F. and Schrag, D.P. 2002. The snowball Earth hypothesis: testing the limits of global change. Terra Nova, 14: 129-155. 
Jensen, P.A. and Wulff-Pedersen, E. 1996. Glacial or non-glacial origin of the Bigganjarga tillite, Finnmark, northern Norway. Geological Magazine, 133: 137-145.

Jensen, P.A. and Wulff-Pedersen, E. 1997. Reply to discussion on glacial or non-glacial origin for the Bigganjargga tillite, Finnmark, northern Norway. Geological Magazine, 134: 873-876.

Kaufman, A.J., Knoll, A.H. and Narbonne, G.M. 1997. Isotopes, ice ages, and terminal Proterozoic Earth history. Proceedings of the National Academy of Science, 94: 6600-6605.

Kellerhals, P. and Matter, A. 2003. Facies analysis of a glaciomarine sequence, the Neoproterozoic Mirbat Sandstone Formation, Sultanate of Oman. Eclogae Geologicae Helveticae, 96: 49-70.

Kendall, B.S., Creaser, R.A. and Selby, D. 2006. Re-Os geochronology of postglacial black shales in Australia: Constraints on the timing of the "Sturtian" glaciation. Geology 34: 729-732.

Kennedy, M.J., Arthur, M.A., Runnegar, B., Prave, A.R. and Hoffmann, K.-H. 1998. Two or four Neoproterozoic glaciations? Geology, 26: 1059-1063.

Knoll, A.H. 2000. Learning to tell Neoproterozoic time. Precambrian Research, 100: 3-20. 
Laajoki, K. 2001. Additional observations on the late Proterozoic Varangerfjorden unconformity, Finnmark, northern Norway. Bulletin of the Geological Society of Finland, 73: 1734.

Laajoki, K. 2002. New evidence of glacial abrasion of the Late Proterozoic unconformity around Varangerfjorden, northern Norway. In: Precambrian sedimentary environments: a modern approach to ancient depositional systems (Eds W. Altermann and P. Corcoran), 33, pp. 450. Blackwell Science, Oxford.

Laajoki, K. 2003. The LarajФg'gi outcrop - a large combined Neoproterozoic/Pleistocene roche moutonnée at Karlebotn, Finnmark, North Norway. Norwegian Journal of Geology, 84: 107-115.

Lawson, D.E. 1982. Mobilisation, movement, and deposition of active subaerial sediment flows, Matanuska Glacier, Alaska. Journal of Geology, 90: 279-300.

Le Heron, D.P., Sutcliffe, O.E., Whittington, R.J. and Craig, J. 2005. The origins of glacially related soft-sediment deformation structures in Upper Ordovician glaciogenic rocks: implications for ice-sheet dynamics. Paleogeography, Paleoclimatology, Paleoecology, 218: 75-103.

Maltman, A. 1994. The geological deformation of sediments. Chapman \& Hall, London, 362 pp.

McCarroll, D. and Rijsdijk, K.F. 2003. Deformational styles as key for interpreting glacial 
depositional environments. Journal of Quaternary Science, 18: 473-489.

Mulder, T. and Alexander, J. 2001. The physical character of subaqueous sedimentary density flows and their deposits. Sedimentology, 48: 269-299.

Nardin, T.R., Hein, F.J., Gorsline, D.S. and Edwards, B.D. 1979. A review of mass movement processes, sediment and acoustic characteristics and contrasts in slope and base of slope systems versus canyon-fan basin floor systems. In: Geology of Continental Slopes (Eds L.J. Doyle and O.H. Pilkey), Society of Economic Paleontologists and Mineralogists, Special Publication, 27, pp. 61-73.

Obermeier, S.F. 1996. Use of liquefaction-induced features for paleoseismic analysis - an overview of how seismic liquefaction features can be distinguished from other features and how their regional distribution and properties of source sediment can be used to infer the location and strength of Holocene paleo-earthquakes. Engineering Geology, 44: 1-76.

Owen, G. 1987. Deformation processes in unconsolidated sands. In: Deformation of sediments and sedimentary rocks (Eds M.E. Jones and R.M.F. Preston), 29, pp. 11-24. Geological Society Special Publication.

Pazos, P.J., Sanchez-Bettucci, L. and Tofalo, O.R. 2003. The record of the Varanger glaciation at the Rio de la Plata Craton, Vendian-Cambrian of Uruguay. Gondwana Research, 6: 65-77. 
Phillips, E.R., Evans, D.A.J. and Auton, C.A. 2002. Polyphase deformation at an oscillating ice margin following the Loch Lomond Readvance, central Scotland, UK. Sedimentary Geology, 149: $157-182$.

Reading, H.G. and Walker, R.G. 1966. Sedimentation of Eocambrian tillites and associated sediments in Finnmark, Northern Norway. Palaeogeography, Palaeoclimatology, Palaeoecology, 2: 177-212.

Rice, A.H.N. 2004. Glacial influence on Neoproterozoic sedimentation: the Smalfjord Formation, nothern Norway - discussion. Sedimentology, 51: 1-4.

Rice, A.H.N. and Hofmann, C.-C. 2000. Evidence for a glacial origin of Neoproterozoic III striations at Oaibaccannjar'ga, Finnmark, northern Norway. Geological Magazine, 137: 355-366.

Rijsdijk, K.F. 2001. Density-driven deformation structures in glacigenic consolidated diamicts: examples from Traeth Y Mwnt, Cardiganshire, Wales, U. K. Journal of Sedimentary Research, 71: $122-135$.

Roberts, D. and Siedlecka, A. 2002. Timanian orogenic deformation along the northeastern margin of Baltica, Northwest Russia and Northeast Norway, and Avalonian-Cadomian connections. Tectonophysics, 352: 169-184. 
Rpe, S.-L. 2003. Neoproterozoic peripheral-basin deposits in eastern Finnmark, N. Norway: stratigraphic revision and palaeotectonic implications. Norwegian Journal of Geology (Norsk Geologisk Tidsskrift), 83: 259-274.

Schermerhorn, L.J.G. 1974. Late Precambrian mixtites: glacial and/or non-glacial. American Journal of Science, 274: 673-824.

Siedlecka, A. 1975. Late Precambrian stratigraphy and structure of the northeastern margin of the Fennoscandian shield (East Finnmark-Timan Region). Norges Geologiske Undersokelse, 316: $313-348$.

Siedlecka, A. 1990. Varangerbotn berggrunnskart 2335 III. Norges geologiske unders $\rho$ ?kelse.

Siedlecka, A. 1991. Nesseby berggrunnskart 2335 II. Norges geologiske unders $\rho$ ?kelse.

Siedlecka, A. and Roberts, D. 1992. The bedrock geology of Varanger Peninsula, Finnmark, North Norway: an excursion guide. Norges Geologiske Undersokelse, Special Publication, 5. Norges Geologiske Undersokelse, Trondheim, 45 pp.

Siedlecka, A. and Roberts, D. 1995. Neoproterozoic sedimentation and subsequent tectonic deformation in the northern coastal areas of Norway and Russia (extended abstract). In: Geology 
of the eastern Finnmark-western Kola Peninsula region (Eds D. Roberts and O. Nordgulen), 7, pp. 331-332. Norges Geologiske Undersokelse Special Publication, Trondheim.

Siedlecka, A., Roberts, D., Nystuen, J.P. and Olovyanishikov, V.G. 2004. Northeastern and northwestern margins of Baltica in Neoproterozoic time: evidence of the Timanian and Caledonian Orogens. In: The Neoproterozoic Timanide Orogen of Eastern Baltica (Eds D. Gee and V. Pease), 30, pp. 169-190. The Geological Society of London, London.

Spjeldnaes, N. 1964. The Eocambrian glaciation in Norway. Geologisches Rundschau, 54: 2445.

Sturt, B.A., Pringle, I.R. and Roberts, D. 1975. Caledonian nappe sequence of Finnmark, northern Norway, and the timing of the orogenic deformation and metamorphism. Geological Society of America Bulletin, 86: 710-718.

Torsvik, T.H., Lohman, K.C. and Sturt, B.A. 1995. Vendian glaciations and their relation to the dispersal of Rodinia: Paleomagnetic constraints. Geology, 23: 727-730.

Torsvik, T.H., Smethurst, M.A., Meert, J.G., Van der Voo, R., McKerrow, W.S., Brasier, M.D., Sturt, B.A. and Walderhaug, H.J. 1996. Continental break-up and collision in the Neoproterozoic and Palaeozoic- a tale of Baltica and Laurentia. Earth Science Reviews, 40: 229258. 
Vidal, G. and Moczydlowska, M. 1995. The Neoproterozoic of Baltica: stratigraphy, palaeobiology and general geological evolution. Precambrian Research, 73: 197-216.

Visser, J.N.J., Colliston, W.P. and Terblanche, J.C. 1984. The origin of soft-sediment deformation structures in permo-carboniferous glacial and proglacial beds, south Africa. Journal of Sedimentary Petrology, 54: 1183-1196.

Winsemann, J., Asprion, U., Meyer, T., Schultz, H. and Victor, P. 2003. Evidence of icebergploughing in a subaqueous ice-contact fan, glacial Lake Rinteln, NW Germany. Boreas, 32: 386398. 


\section{FIGURE CAPTIONS}

Figure 1: Geological map of the study area (after Siedlecka, 1990, 1991).

Figure 2: Stratigraphy and geochronology of the Smalfjord Formation in Northern Norway (modified from Siedlecka and Roberts, 1992, Arnaud and Eyles, 2002). Dotted lines are erosional unconformities. Ages are based on Rb-Sr whole-rock isochron (Sturt et al., 1975; Gorokhov et al. (2001) suggested the Smalfjord, Nyborg and Mortensnes formations were deposited between 630-560 Ma, based on $\mathrm{Rb}-\mathrm{Sr}$ dating of diagenetic illite in shales of the Stangenes and Nyborg formations. Ediacaran fauna were described from the Innerelv Member of the Stappogiedde Formation (Farmer et al., 1992). The Cambrian boundary is thought to be within the basal sandstones of the Breivika Formation (Vidal and Moczydłowska, 1995).

Figure 3: Sedimentary facies of the Smalfjord Formation in the study area. A) Crude horizontal bedding (5-20 cm scale) in conglomerate with stratification defined by changes in the abundance and size of clasts, Log H03-7, site \#1, Handelsneset; B) Poorly-sorted and deformed conglomerate overlying sandstone of the Fugleberget Formation, Site \#3, Handelsneset; C) inverse grading in conglomerate, Log H03-5, Site \#1, Handelsneset; D) massive mediumgrained sandstone interbedded with finely laminated muddy sandstone, East Skjaholmen. Note loaded basal contacts; E) channelized sandstone, south-central Skjaholmen. Sandstone in the upper third of the photograph is laterally equivalent to the massive and graded sandstone of logs S03-2 to S03-6 in Fig. 5A; F) diamictite lens overlain by boulder conglomerate. Person is standing on sandstone of the Smalfjord Formation with the upper contact of the diamictite at 
shoulder height (see Figure 4A for overall geometry of diamictite unit).

Figure 4: A) Field sketch showing part of the exposure and distribution of sediment types at Skjaholmen, eastern shore. No vertical exaggeration. Shading within diamictite unit represents an area of finer-grained matrix; B) Detailed logs showing sediment types at Skjaholmen, eastern shore. The location of S-03-9 is identified in (A); S-03-10 and S-03-8 were measured laterally on either side of the outcrop shown in (A). The cross-bedded sandstone at the base of S-03-8 (shaded) is from the underlying Veinesbotn Formation (Siedlecka, 1990; 1991; Gamasfjellet Formation according to Rpe, 2003); C) symbols and lithofacies code used in this study.

Figure 5: A) Detailed logs showing sediment types at Skjaholmen, south-central shore. The vertical position of the logs relative to each other was established using marker beds in the underlying sandstones of the Veinesbotn Formation (grey). Note significant erosion of the Veinesbotn Formation at the base of the Smalfjord Formation. See Fig. 4C for symbols and lithofacies codes; B) Field sketch of the lowermost bed of the Smalfjord Formation showing brecciation of underlying Veinesbotn Formation sandstone (light grey) between logs S-03-5 and S-03-6 as well as stratified nature of basal Smalfjord Formation sediments overlying the unconformity, south-central shore, Skjaholmen. Dark grey units are fine and muddy sandstone. See text for discussion.

Figure 6: Schematic diagram of study sites at Handelsneset (modified from Edwards, 1984) and structural data (this study) showing the relief and variable dip on the Smalfjord Formation basal 
unconformity, and the distribution of sediments at these sites. Inset map shows plan view of Handelsneset outcrops.

Figure 7: A) Detailed sedimentological logs of Site \#1, Handelneset. Inset plan-view map shows relative location of logs; B) Schematic diagram showing lateral continuity and geometry of units in Site \#1 to scale. Note the backstepping and progradational trend of the conglomeratic units (dark grey). The steepest clinoform has an 11E dip. See Fig. 4C for symbols and lithofacies code.

Figure 8: A) Cross-section exposure measured in the field showing geometry of conglomerate (dark grey) and sandstone (light grey) units and location of detailed sedimentological logs at Site \#4, Handelsneset. The white unit consists of stratified, matrix supported conglomerate and deformed sandstone at the ENE end of the outcrop. These facies laterally change into horizontally laminated sandstone at $\log \mathrm{H}-03-11$ and H-03-12, and back to stratified, matrixsupported conglomerate and deformed sandstone at the WSW end of the outcrop. The unconformity at this site has a dip of 3E; B) Diagram shown in (A), without vertical exaggeration; C) logs from Site \#4, Handelsneset. A massive sandstone marker bed within the Fugleberget Formation (grey) was used as a datum for the stratigraphic logs. See Fig. 4C for symbols and lithofacies code and text for discussion.

Figure 9: Smalfjord Formation sediments at Nesseby: A) Field sketch showing lateral continuity and geometry of sandstone and conglomerate beds B) Detailed logs showing typical facies 
exposed. See Fig. 4C for symbols and lithofacies code.

Figure 10: Deformation structures in conglomerate and sandstone of the Smalfjord Formation. General view (A) and close up (B) of small flow nose (white arrow), Panel 7, Site \#3, Handelsneset. Note lighter-coloured conglomerate being incorporated at the base of the flow nose (white arrow) in (B) and basal unconformity with the underlying cross-bedded sandstone of the Fugleberget Formation (white dotted line in (A); C) and D) two adjacent photographs showing recumbent folding in sandstone (circled) and conglomerate (white arrow) in relation to inclined depositional surface (black arrow), southwest Skjaholmen; E) close up of inclined isoclinal folding in conglomerate indicated with an arrow in (C); F) close up of recumbent isoclinal folding in sandstone, indicated with a circle in (C); G) shearing structures, Panel 3, Site \#3, Handelsneset; H) Contorted and convoluted bedding, Panel 3, Site \#3, Handelsneset; I) field sketch of deformed conglomerate and sandstone showing highly variable and complex deformation styles, Site \#3, Handelsneset. Note undeformed cross-bedded conglomerate in bottom half of left panel. These are predominantly conglomerates, with minor pebbly sandstoneclasts are drawn in to emphasize relatively abundant or relatively large clasts in certain areas. Shaded areas appear brown in the field, in contrast to the white areas, which appears light beige in the field. These colour differences are due to variable matrix lithology; J) close-up photographs showing shear plane and complex deformation associated with the ridge; see text for discussion K) general view of the ridge like-feature; L) close up of large conglomeratic flow nose. 
Figure 11: Field sketches showing rapid lateral facies changes and various amounts of deformation in deformed (Units A and C) and undeformed zones (Units B and D), the Smalfjord Formation at Site \#3, Handelsneset. These are predominantly conglomerates, with minor pebbly sandstone- clasts are drawn in to emphasize relatively abundant or relatively large clasts in certain areas. Shaded areas appear brown in the field, in contrast to the white areas, which appears light beige in the field. These colour differences are due to variable matrix lithology. Red arrows highlight apparent direction of shear structures. Horizontally- or cross-bedded sandstone of the underlying Fugleberget Formation (yellow) can be seen in all panels except panels 4 and 5. Inset plan view map shows relative position of panels. See text for discussion. 


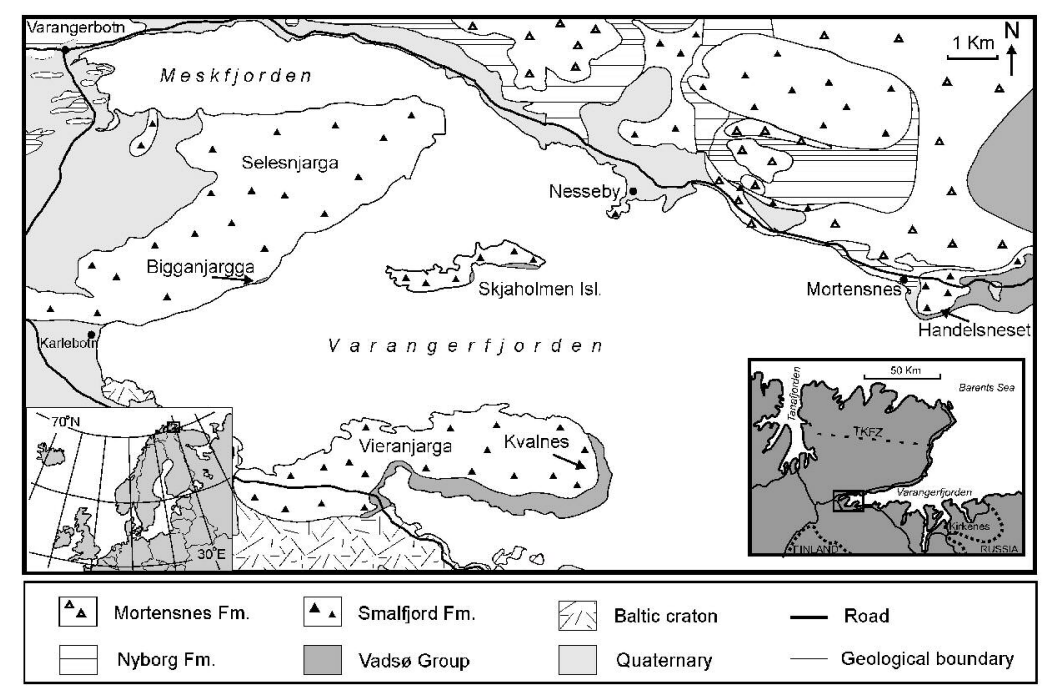

Arnaud, Fig. 1

Figure 1: Geological map of the study area (after Siedlecka, 1990, 1991). 


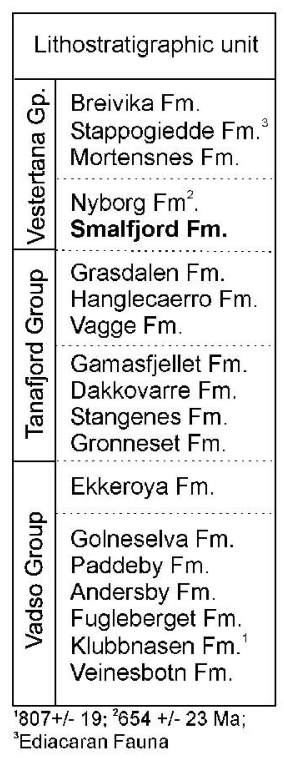

Figure 2: Stratigraphy and geochronology of the Smalfjord Formation in Northern Norway (modified from Siedlecka and Roberts, 1992, Arnaud and Eyles, 2002). Dotted lines are erosional unconformities. Ages are based on Rb-Sr whole-rock isochron (Sturt et al., 1975; Gorokhov et al. (2001) suggested the Smalfjord, Nyborg and Mortensnes formations were deposited between 630-560 Ma, based on Rb-Sr dating of diagenetic illite in shales of the Stangenes and Nyborg formations. Ediacaran fauna were described from the Innerelv Member of the Stappogiedde Formation (Farmer et al., 1992). The Cambrian boundary is thought to be within the basal sandstones of the Breivika Formation (Vidal and Moczydłowska, 1995). 

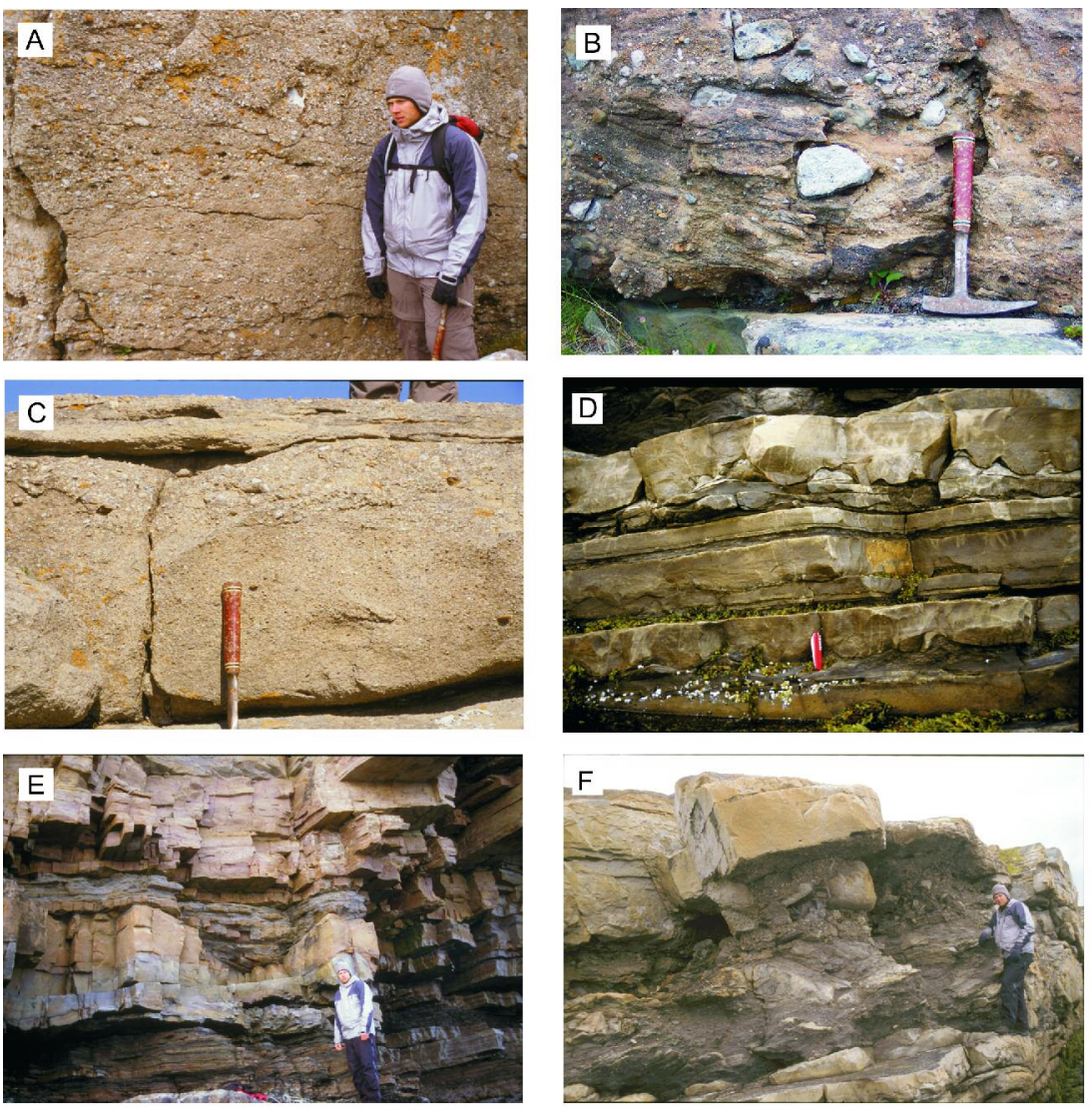

Figure 3: Sedimentary facies of the Smalfjord Formation in the study area. A) Crude horizontal bedding (5-20 cm scale) in conglomerate with stratification defined by changes in the abundance and size of clasts, Log H03-7, site \#1, Handelsneset; B) Poorlysorted and deformed conglomerate overlying sandstone of the Fugleberget Formation, Site \#3, Handelsneset; C) inverse grading in conglomerate, Log H03-5, Site \# 1, Handelsneset; D) massive medium-grained sandstone interbedded with finely laminated muddy sandstone, East Skjaholmen. Note loaded basal contacts; E) channelized sandstone, south-central Skjaholmen. Sandstone in the upper third of the photograph is laterally equivalent to the massive and graded sandstone of logs S03-2 to S03-6 in Fig. 5A; F) diamictite lens overlain by boulder conglomerate. Person is standing on sandstone of the Smalfjord Formation with the upper contact of the diamictite at shoulder height (see Figure 4A for overall geometry of diamictite unit). 

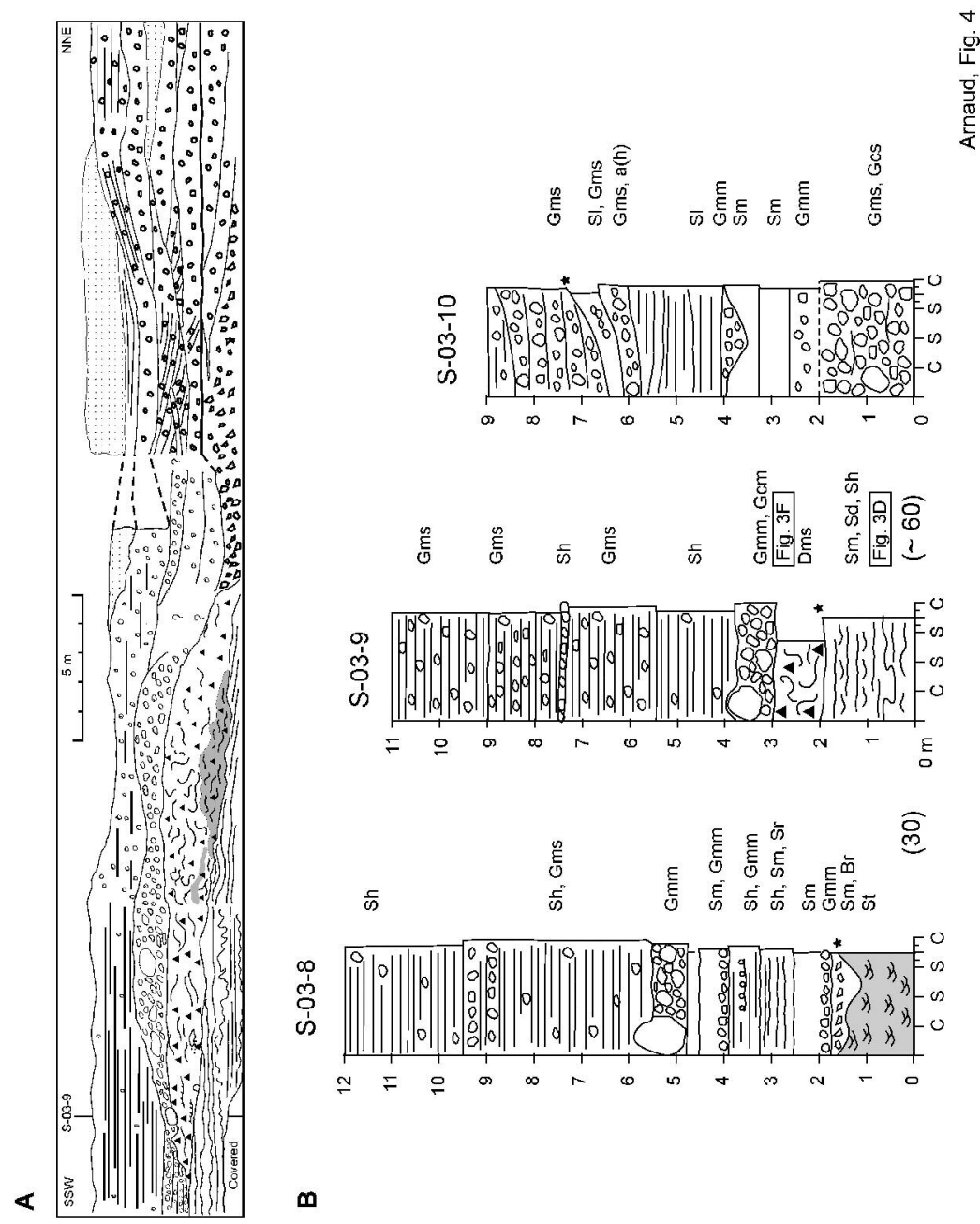

m

Figure 4: A) Field sketch showing part of the exposure and distribution of sediment types at Skjaholmen, eastern shore. No vertical exaggeration. Shading within diamictite unit represents an area of finer-grained matrix; B) Detailed logs showing sediment types at Skjaholmen, eastern shore. The location of S-03-9 is identified in (A); S-03-10 and S-03-8 were measured laterally on either side of the outcrop shown in (A). The cross-bedded sandstone at the base of S-03-8 (shaded) is from the underlying Veinesbotn Formation (Siedlecka, 1990; 1991; Gamasfjellet Formation according to Røe, 2003). 


\begin{tabular}{|c|c|c|c|c|c|c|}
\hline \multirow[t]{6}{*}{ C } & $\begin{array}{l}\text { Gmm/Gcm } \\
\text { Gms/Gcs } \\
G p \\
G t \\
G m g / G c g \\
G I \\
a(\text { (h) } \\
\text { (d) } \\
\text { Br }\end{array}$ & \multicolumn{3}{|c|}{$\begin{array}{l}\text { matrixiclast supported, massive } \\
\text { matrixclast supported, stratified } \\
\text { planar cross-bedded } \\
\text { trough cross-bedded } \\
\text { matrix/clast supported, graded } \\
\text { low angle cross-bedded } \\
\text { a-axis, horizontal } \\
\text { deformed } \\
\text { Breccia }\end{array}$} & Contacts & $\begin{array}{l}\text { Covered } \\
\text { Sharp, erosive } \\
\text { Sharp, irregular } \\
\text { Sharp, planar } \\
\text { Gradational } \\
\text { Interbedded } \\
\text { Loaded }\end{array}$ \\
\hline & $\begin{array}{l}\text { Sh } \\
\text { si } \\
\text { Sr } \\
\text { Si } \\
\text { sp } \\
\text { Sm } \\
\text { Sc } \\
\text { Sg }\end{array}$ & \multicolumn{3}{|c|}{$\begin{array}{l}\text { deformed } \\
\text { horizontally laminated } \\
\text { low-angle laminated } \\
\text { rippled } \\
\text { trough cross bedded } \\
\text { planar cross-bedded } \\
\text { massive } \\
\text { pebbly sandstone } \\
\text { graded }\end{array}$} & 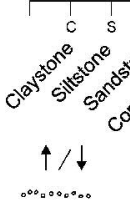 & $\begin{array}{c}m \text { - medium } \\
c \text { - coarse }\end{array}$ \\
\hline & $\begin{array}{l}\text { Fine-grain } \\
\mathrm{FI} \\
\text { Dms }\end{array}$ & 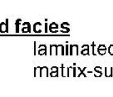 & spported, s & atified & $\begin{array}{l}{ }^{2000000000} \\
\text { Fig. } 8 \mathrm{~A} \\
(900 \mathrm{~m})\end{array}$ & $\begin{array}{l}\text { layers } \\
\text { on of photographs } \\
\text { ce between logs }\end{array}$ \\
\hline & $\equiv$ & Laminated & AS & $\begin{array}{l}\text { Diamiclite, } \\
\text { with rafts }\end{array}$ & Iratified, & $\begin{array}{l}\text { Cross-bedded } \\
\text { planar }\end{array}$ \\
\hline & $=$ & Low angle & 00 & Conglome & & $\begin{array}{l}\text { Cross-bedded, } \\
\text { trough }\end{array}$ \\
\hline & $\begin{array}{ll}35 \\
03\end{array}$ & Deformed & 80 & Breccia & & Rippled \\
\hline
\end{tabular}

Arnaud, Fig. 4 cont

Figure 4: C) symbols and lithofacies code used in this study. 


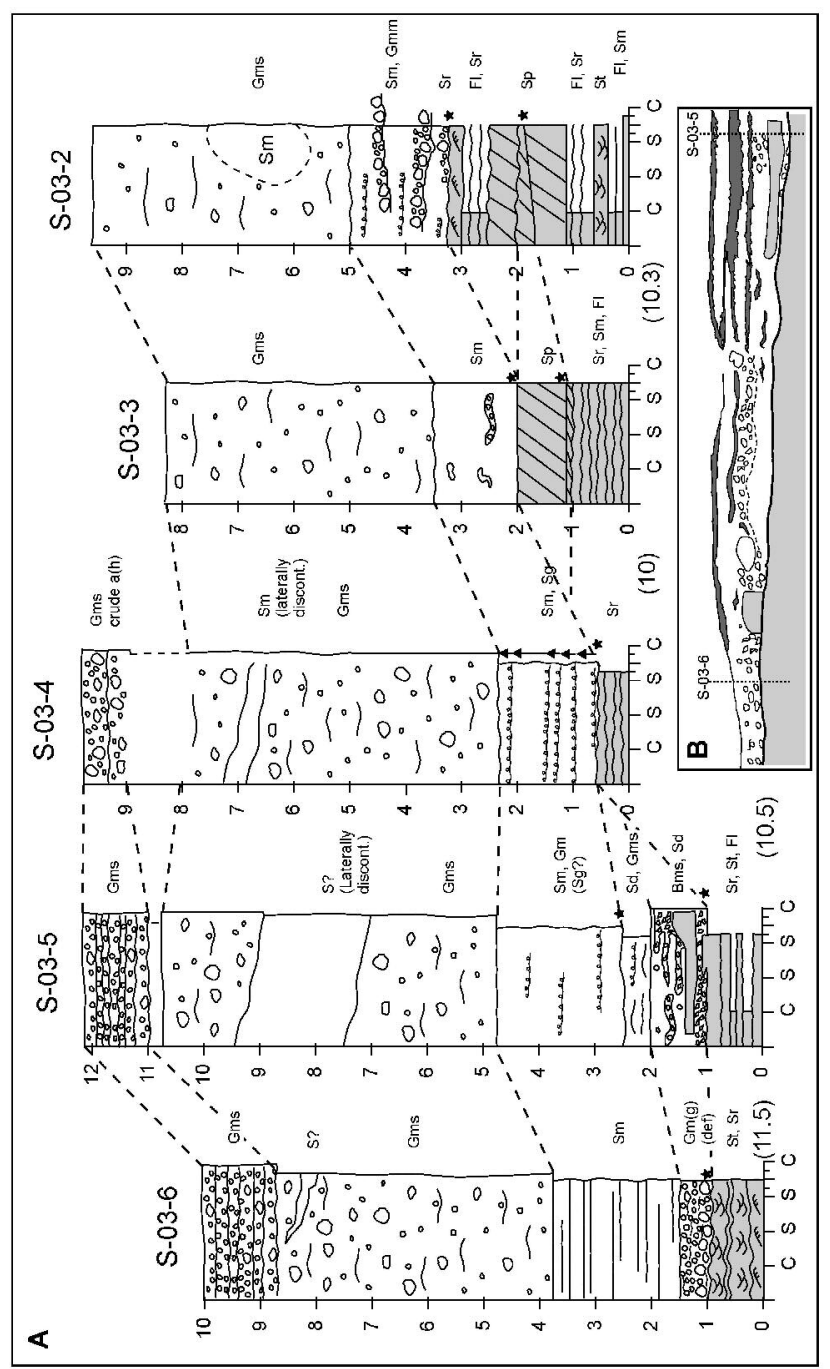

Figure 5: A) Detailed logs showing sediment types at Skjaholmen, south-central shore. The vertical position of the logs relative to each other was established using marker beds in the underlying sandstones of the Veinesbotn Formation (grey). Note significant erosion of the Veinesbotn Formation at the base of the Smalfjord Formation. See Fig. 4C for symbols and lithofacies codes; B) Field sketch of the lowermost bed of the Smalfjord Formation showing brecciation of underlying Veinesbotn Formation sandstone (light grey) between logs S-03-5 and S-03-6 as well as stratified nature of basal Smalfjord Formation sediments overlying the unconformity, south-central shore, Skjaholmen. Dark grey units are fine and muddy sandstone. See text for discussion. 


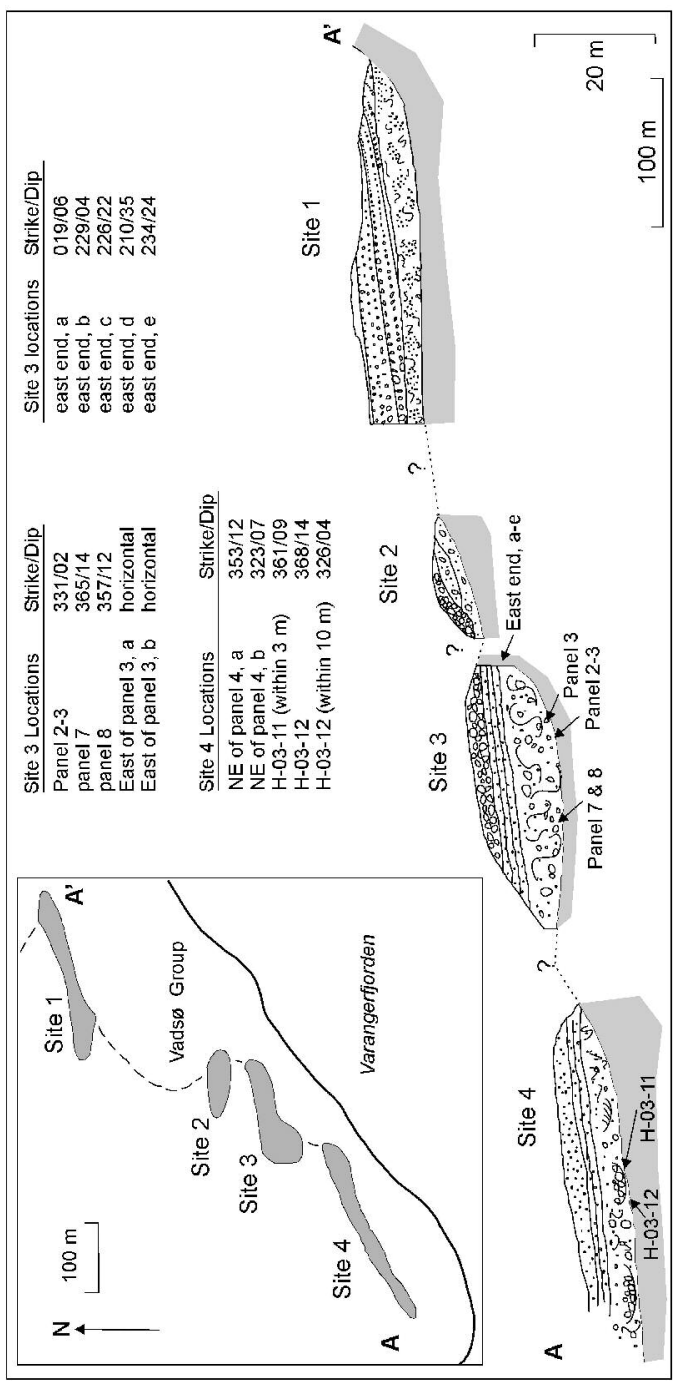

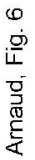

Figure 6: Schematic diagram of study sites at Handelsneset (modified from Edwards, 1984) and structural data (this study) showing the relief and variable dip on the Smalfjord Formation basal unconformity, and the distribution of sediments at these sites. Inset map shows plan view of Handelsneset outcrops. 


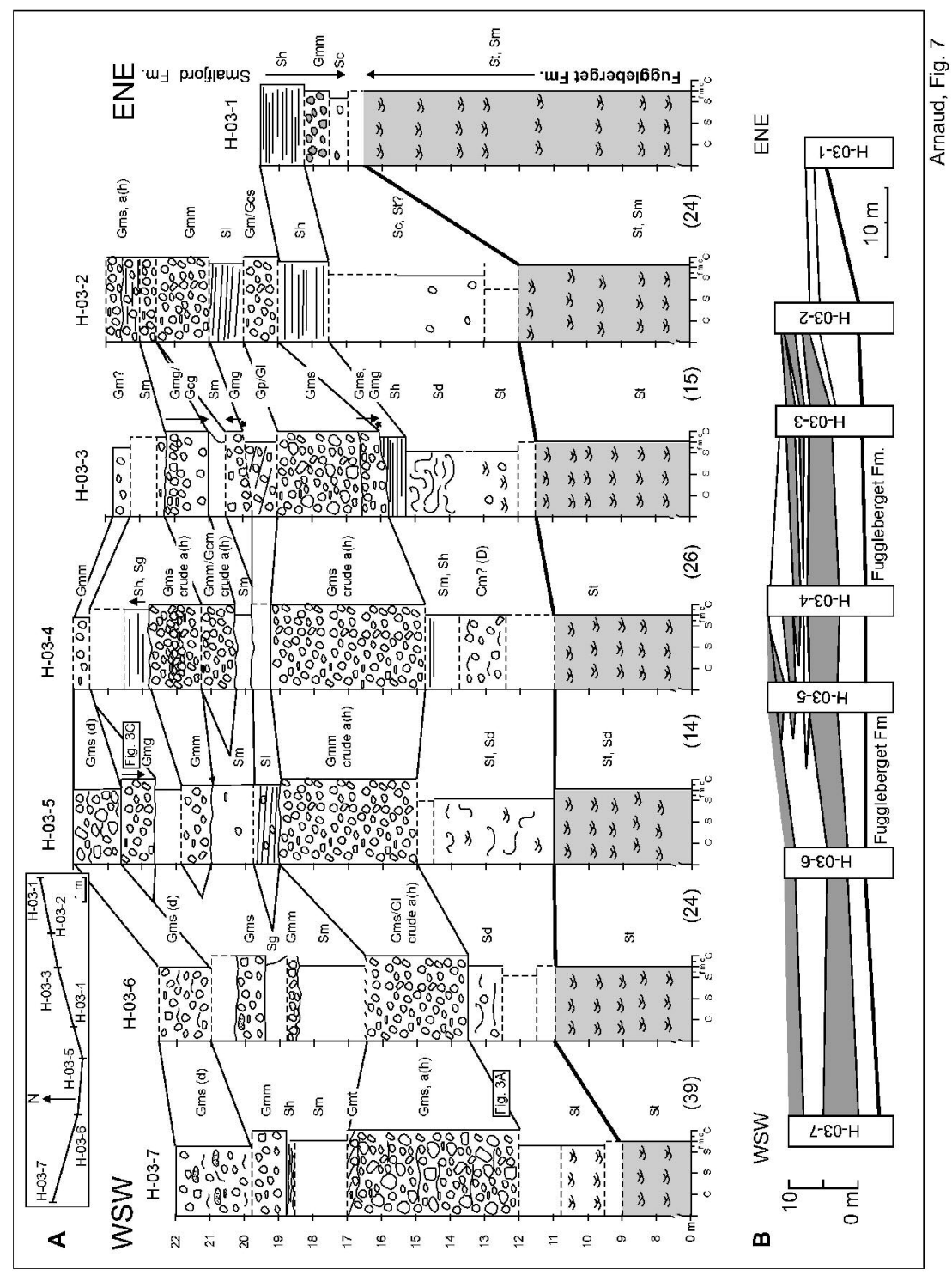

Figure 7: A) Detailed sedimentological logs of Site \# 1, Handelneset. Inset plan-view map shows relative location of logs; B) Schematic diagram showing lateral continuity and geometry of units in Site \#1 to scale. Note the backstepping and progradational trend of the conglomeratic units (dark grey). The steepest clinoform has an $11^{\circ}$ dip. See Fig. 4C for symbols and lithofacies code. 


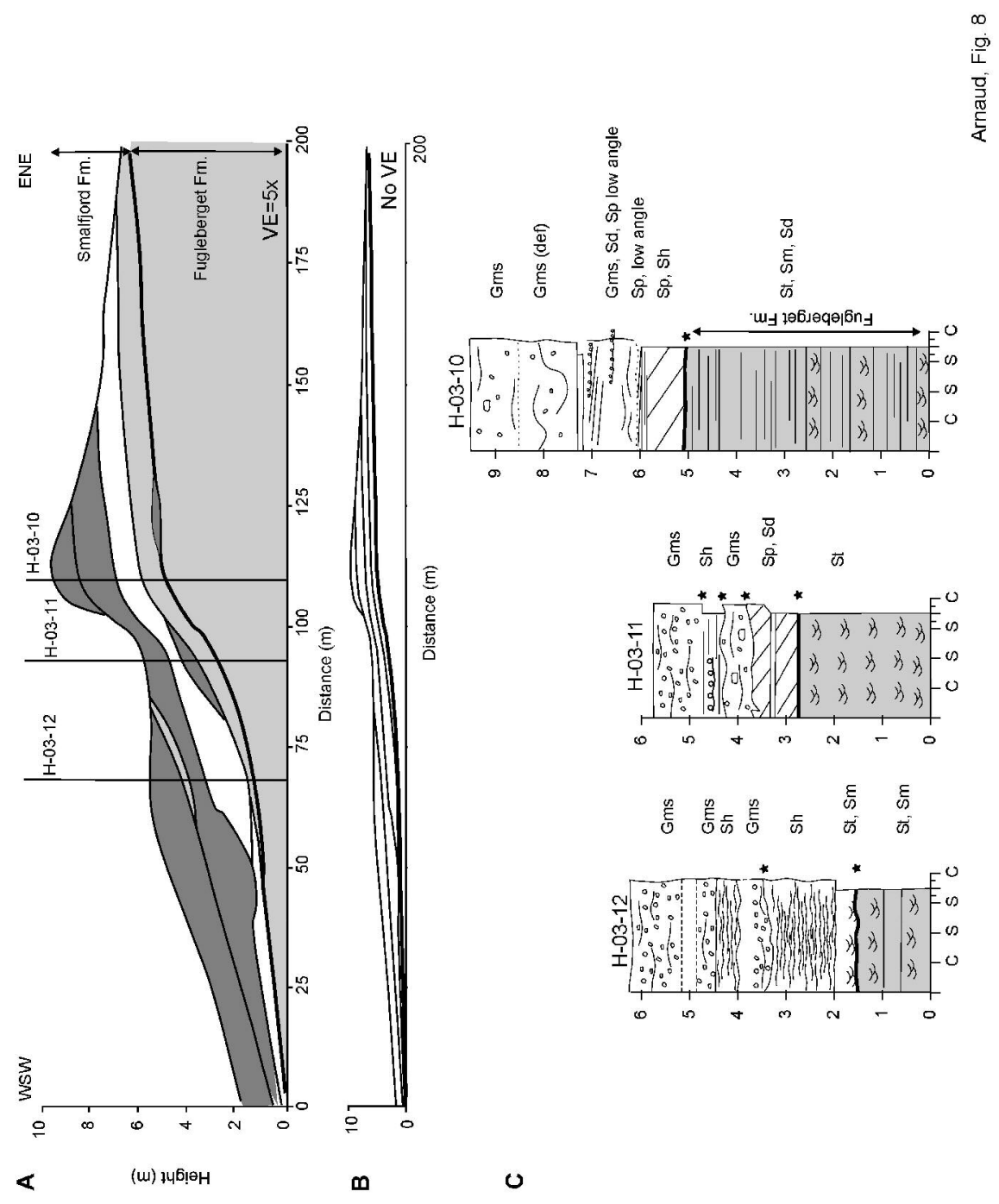

Figure 8: A) Cross-section exposure measured in the field showing geometry of conglomerate (dark grey) and sandstone (light grey) units and location of detailed sedimentological logs at Site \#4, Handelsneset. The white unit consists of stratified, matrix supported conglomerate and deformed sandstone at the ENE end of the outcrop. These facies laterally change into horizontally laminated sandstone at log $\mathrm{H}-03-11$ and $\mathrm{H}-$ 03-12, and back to stratified, matrix-supported conglomerate and deformed sandstone at the WSW end of the outcrop. The unconformity at this site has a dip of $3^{\circ}$; B) Diagram shown in (A), without vertical exaggeration; C) logs from Site \#4, Handelsneset. A massive sandstone marker bed within the Fugleberget Formation (grey) was used as a datum for the stratigraphic logs. See Fig. 4C for symbols and lithofacies code and text for discussion. 


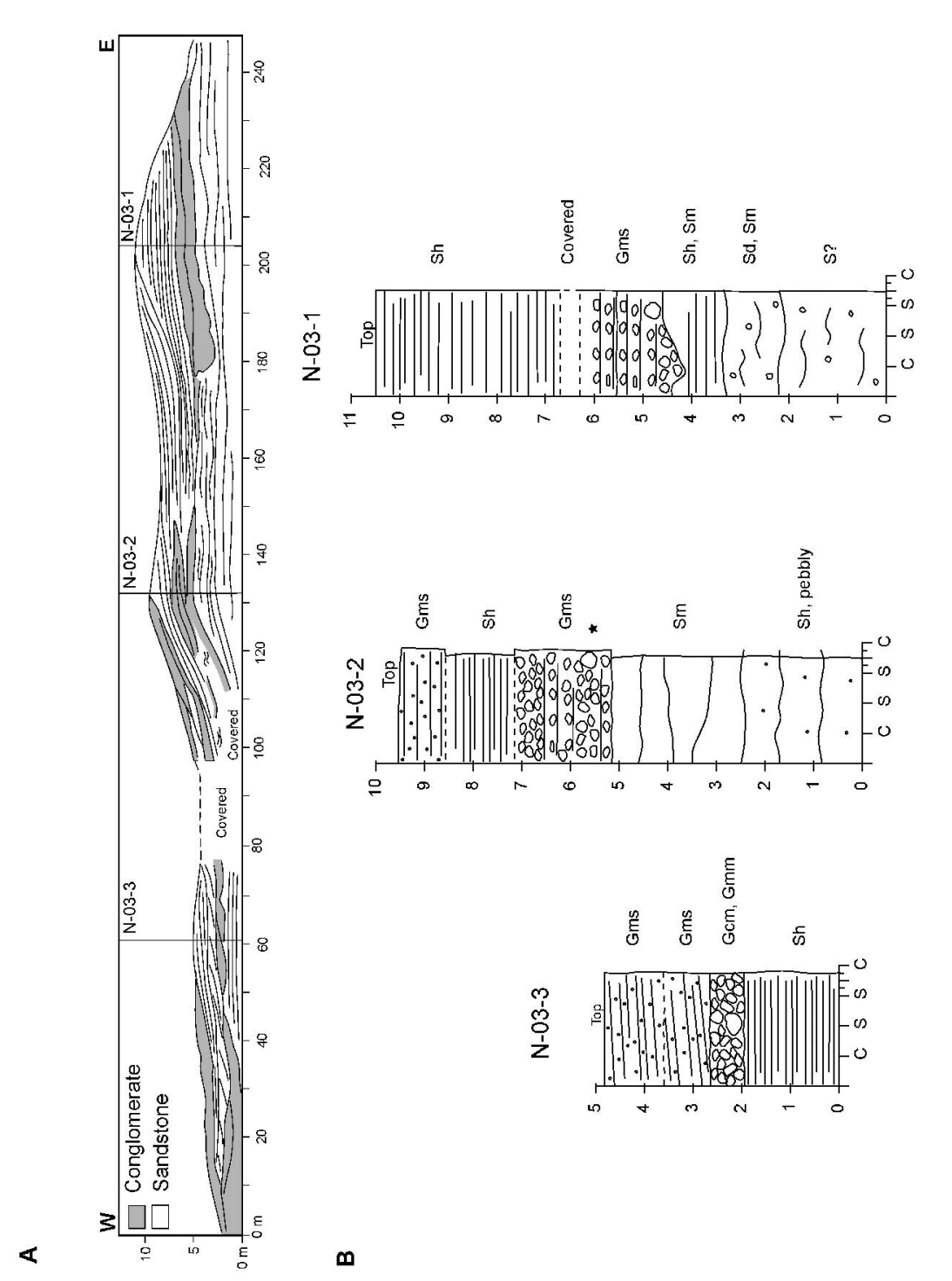

Figure 9: Smalfjord Formation sediments at Nesseby: A) Field sketch showing lateral continuity and geometry of sandstone and conglomerate beds B) Detailed logs showing typical facies exposed. See Fig. 4C for symbols and lithofacies code. 

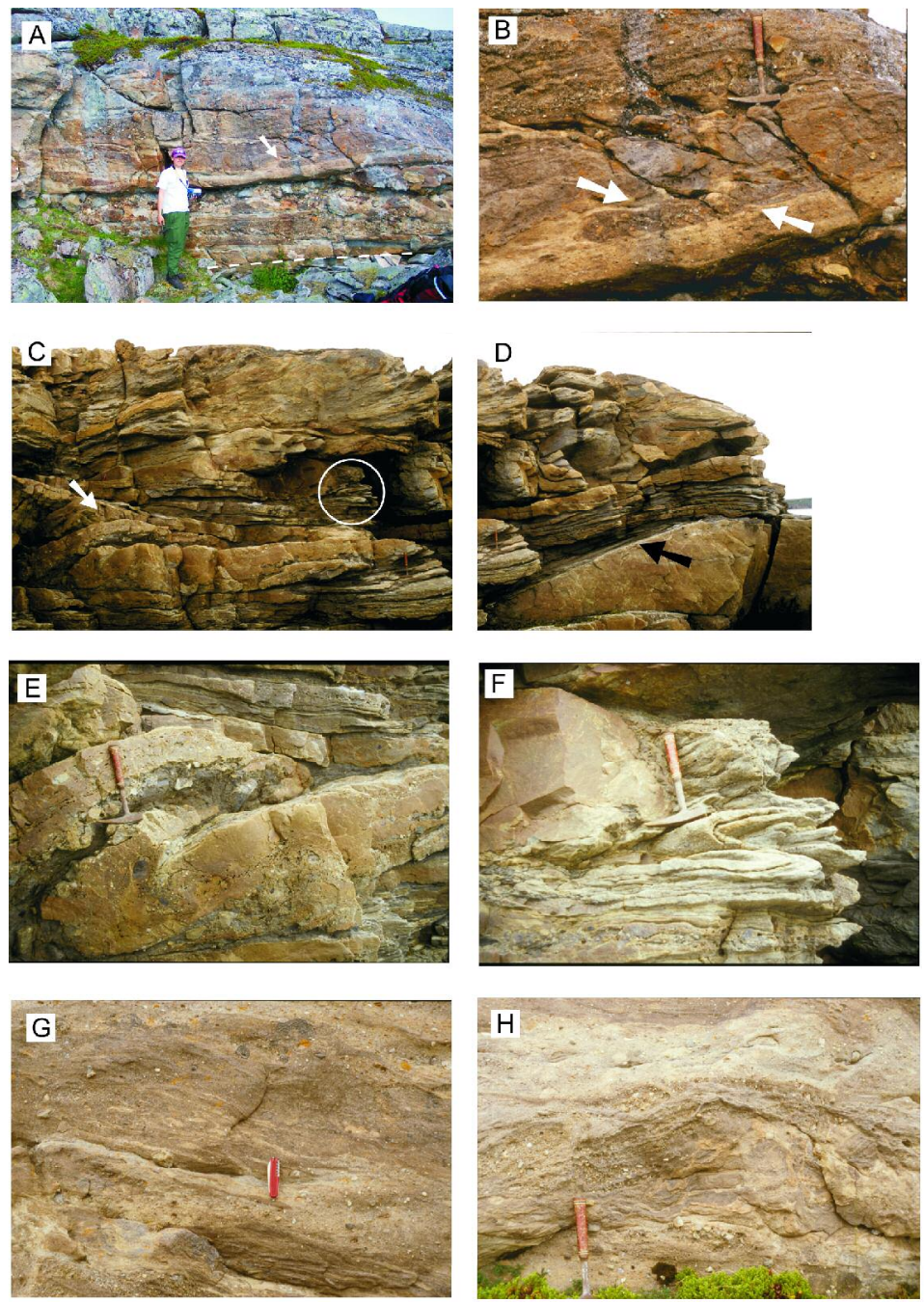

Arnaud, Fig. 10

Figure 10: Deformation structures in conglomerate and sandstone of the Smalfjord Formation. General view (A) and close up (B) of small flow nose (white arrow), Panel 7, Site \#3, Handelsneset. Note lighter-coloured conglomerate being incorporated at the base of the flow nose (white arrow) in (B) and basal unconformity with the underlying cross-bedded sandstone of the Fugleberget Formation (white dotted line in (A); C) and D) two adjacent photographs showing recumbent folding in sandstone (circled) and conglomerate (white arrow) in relation to inclined depositional surface (black arrow), southwest Skjaholmen; E) close up of inclined isoclinal folding in conglomerate indicated with an arrow in (C); F) close up of recumbent isoclinal folding in sandstone, indicated with a circle in (C); G) shearing structures, Panel 3, Site \#3, Handelsneset; H) Contorted and convoluted bedding, Panel 3, Site \#3, Handelsneset 


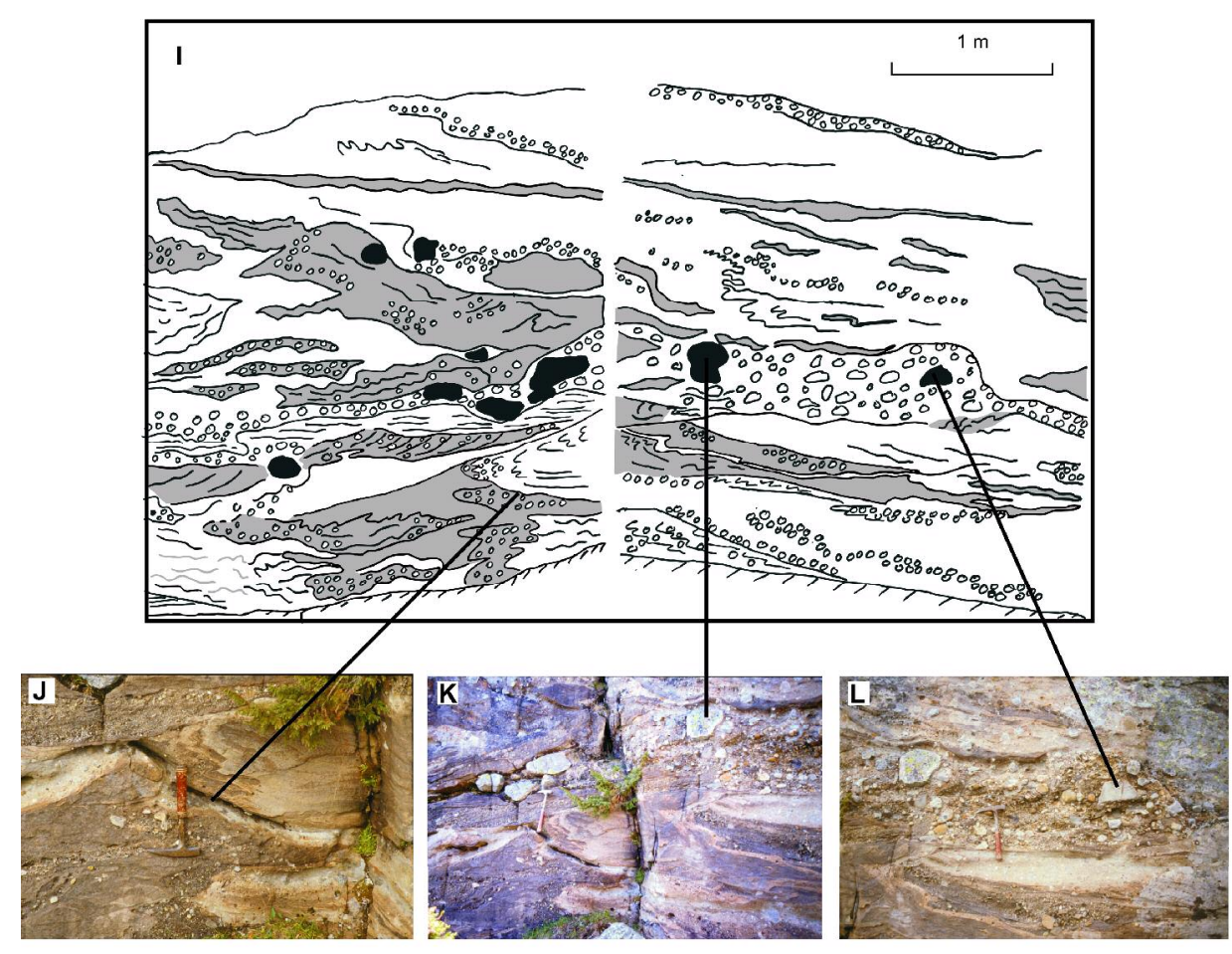

Arnaud, Fig. 10 cont

Figure 10: Deformation structures in conglomerate and sandstone of the Smalfjord Formation. I) field sketch of deformed conglomerate and sandstone showing highly variable and complex deformation styles, Site \#3, Handelsneset. Note undeformed crossbedded conglomerate in bottom half of left panel. These are predominantly conglomerates, with minor pebbly sandstone- clasts are drawn in to emphasize relatively abundant or relatively large clasts in certain areas. Shaded areas appear brown in the field, in contrast to the white areas, which appears light beige in the field. These colour differences are due to variable matrix lithology; J) close-up photographs showing shear plane and complex deformation associated with the ridge; see text for discussion $\mathrm{K}$ ) general view of the ridge like-feature; $L$ ) close up of large conglomeratic flow nose. 


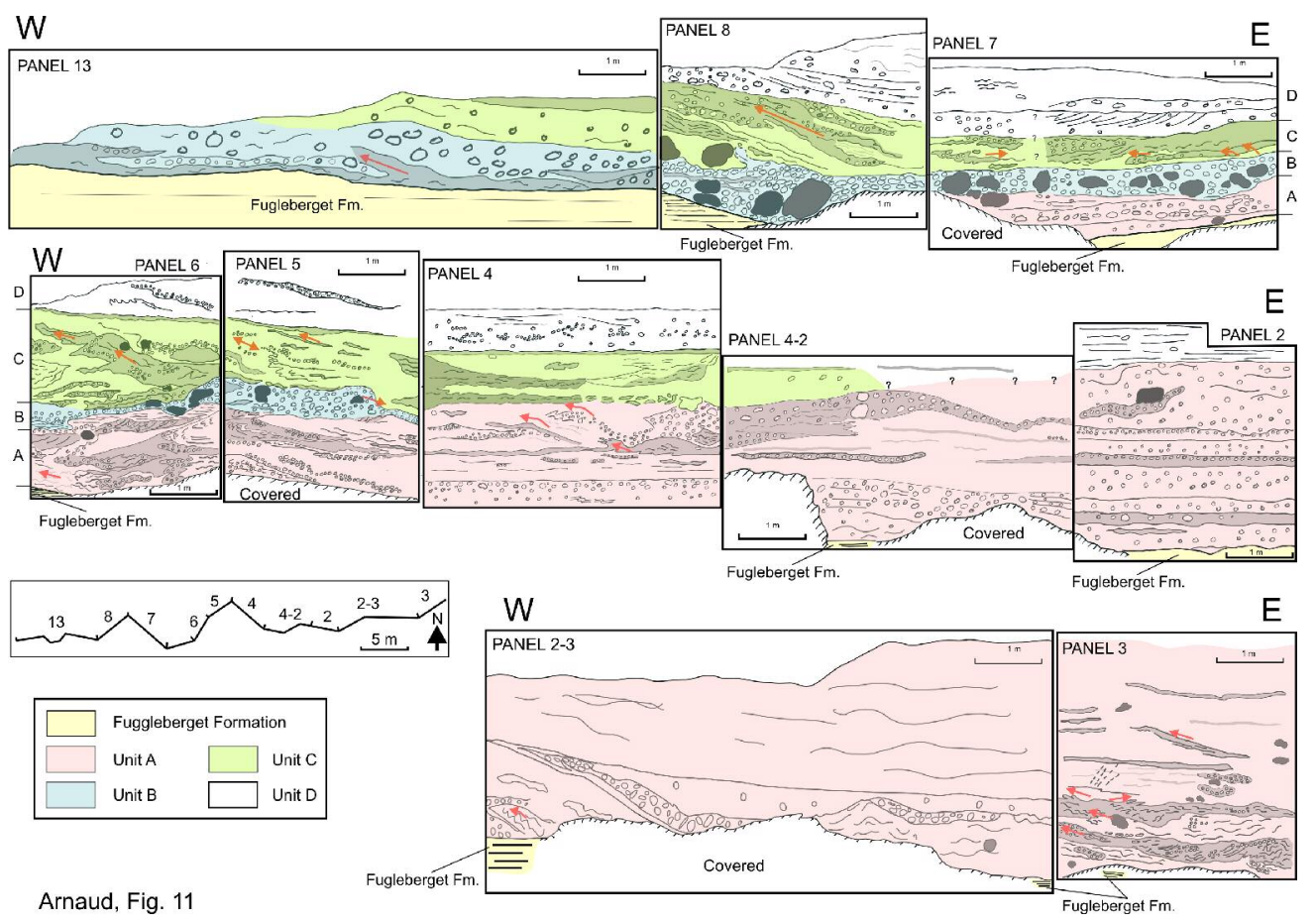

Figure 11: Field sketches showing rapid lateral facies changes and various amounts of deformation in deformed (Units A and C) and undeformed zones (Units B and D), the Smalfjord Formation at Site \#3, Handelsneset. These are predominantly conglomerates, with minor pebbly sandstone- clasts are drawn in to emphasize relatively abundant or relatively large clasts in certain areas. Shaded areas appear brown in the field, in contrast to the white areas, which appears light beige in the field. These colour differences are due to variable matrix lithology. Red arrows highlight apparent direction of shear structures. Horizontally- or cross-bedded sandstone of the underlying Fugleberget Formation (yellow) can be seen in all panels except panels 4 and 5 . Inset plan view map shows relative position of panels. See text for discussion. 